


\section{DISCLAIMER}

This report was prepared as an account of work sponsored by an agency of the United States Government. Neither the United States Government nor any agency Thereof, nor any of their employees, makes any warranty, express or implied, or assumes any legal liability or responsibility for the accuracy, completeness, or usefulness of any information, apparatus, product, or process disclosed, or represents that its use would not infringe privately owned rights. Reference herein to any specific commercial product, process, or service by trade name, trademark, manufacturer, or otherwise does not necessarily constitute or imply its endorsement, recommendation, or favoring by the United States Government or any agency thereof. The views and opinions of authors expressed herein do not necessarily state or reflect those of the United States Government or any agency thereof. 


\section{DISCLAIMER}

Portions of this document may be illegible in electronic image products. Images are produced from the best available original document. 


\section{LEGAL NOTICE}

This report was prepared as an account of work sponsored by the United States Government. Neither the United States nor the United States Atomic Energy Commission, nor any of their employees, nor any of their contractors, subcontractors, or their employees, makes any warranty, expressed or implied, or assumes any legal liability or responsibility for the accuracy, completeness or usefulness of any information, apparatus, product or process disclosed, or represents that its use would not infringe privately owned rights.

Printed in the United States of America

Available from the

National Technical Information Service

U. S. Department of Commerce

Springfield, Virginia 22151

Price: Printed Copy $\$ 4.00$ Microfiche $\$ 1.45$ 
INVESTIGATION OF THE CARBON

\section{TETRACHLORIDE-METHANOL-PLUTONIUM}

METAL SYSTEM

Larry R. Crisler

Chemistry Research and Development CHEMICAL TECHNOLOGY

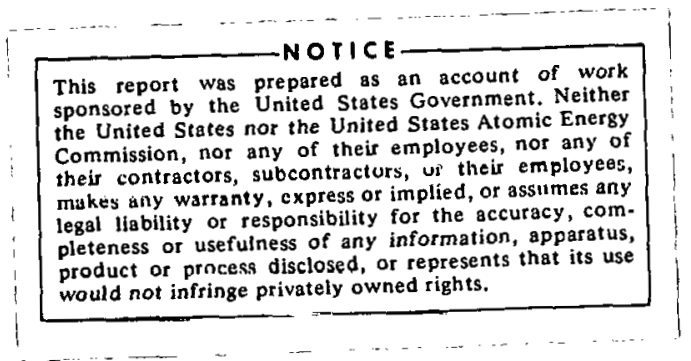

DOW CHEMICAL U.S.A.

ROCKY FLATS DIVISION

P. O. BOX 888

GOLDEN, COLORADO 80401

Prepared under Contract AT(29-1)-1.106

for the

Albuquerque Operations Office

U. S. Atomic Energy Commission
SUBJECT DESCRIPTORS

Tetrachloromethane

Methanol

Plutonium Metal

Sulvents

Reactivity

Plutonium Corrosion 


\section{CONTENTS}

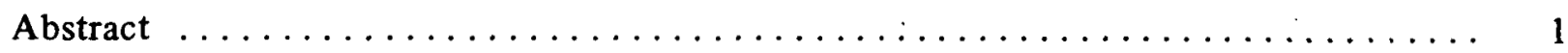

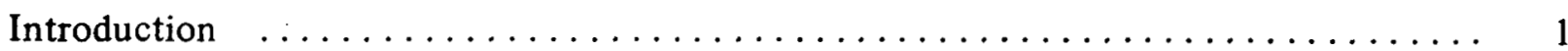

Review of Chemical Reactivity for $\mathrm{CCl}_{4} / \mathrm{CH}_{3} \mathrm{OH} / \mathrm{Pu}^{\circ}$ Reaction Components $\ldots \ldots \ldots \ldots \quad 1$

Carbon Tetrachloride $\ldots \ldots \ldots \ldots \ldots \ldots \ldots \ldots \ldots \ldots \ldots \ldots \ldots \ldots \ldots \ldots \ldots$

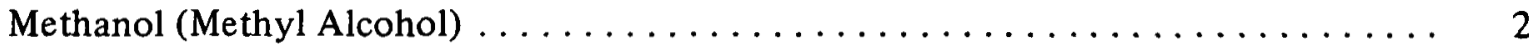

Carbon Tetrachloride and Methanol (Co-Solvent) ................ 3

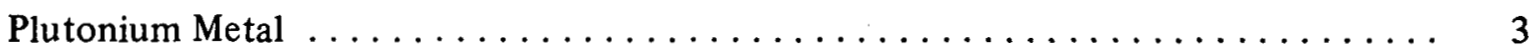

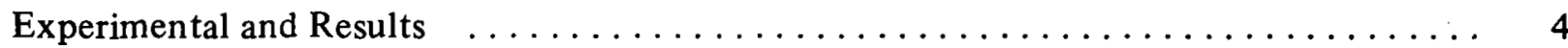

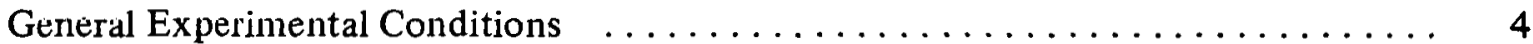

Plutonium Metal Keaction Kates with $\mathrm{CCl}_{4} / \mathrm{CH}_{3} \mathrm{OH} \ldots \ldots \ldots \ldots \ldots \ldots \ldots$

Plutonium Metal Reaction Rate at Ambient Conditions (No Temperature Regulation) ............. 5

Plutonium Metal Reaction Rate at

Subambient Conditions (Temperature Regulated) $\ldots \ldots \ldots \ldots \ldots \ldots 6$

Off-Gas Rates from $\mathrm{CCl}_{4} / \mathrm{CH}_{3} \mathrm{OH} / \mathrm{Pu}^{\circ}$ Reaction $\ldots \ldots \ldots \ldots \ldots \ldots$

Maximum Plutonium Metal Alteration in a Static $\mathrm{CCl}_{4} / \mathrm{CH}_{3} \mathrm{OH} / \mathrm{Pu}^{\circ}$ Reaction System $\ldots \ldots \ldots \ldots \ldots \ldots \ldots \ldots$

Heat of Reaction, $\mathrm{CCl}_{4} / \mathrm{CH}_{3} \mathrm{OH} / \mathrm{Pu}^{\circ} \ldots \ldots \ldots \ldots \ldots \ldots \ldots \ldots \ldots \ldots$

Identification of Products Formed in $\mathrm{CCl}_{4} / \mathrm{CH}_{3} \mathrm{OH} / \mathrm{Pu}^{\circ}$ Reaction $\ldots \ldots \ldots \ldots \ldots$

Electronic Spectra of Plutonium Species

Formed in $\mathrm{CCl}_{4} / \mathrm{CH}_{3} \mathrm{OH} / \mathrm{Pu}^{\circ}$ Reaction Mixtures $\ldots \ldots \ldots \ldots \ldots \ldots \ldots$

Product Precipitated from

$\mathrm{CCl}_{4} / \mathrm{CH}_{3} \mathrm{OH} / \mathrm{Pu}^{\circ}$ Reaction Mixtures $\ldots \ldots \ldots \ldots \ldots \ldots \ldots \ldots \ldots \ldots \ldots$

$\mathrm{pH}$ Investigation of Fresh and Aged $\mathrm{CCl}_{4} / \mathrm{CH}_{3} \mathrm{OH}$ Mixtures $\ldots \ldots \ldots \ldots \ldots \ldots \ldots$

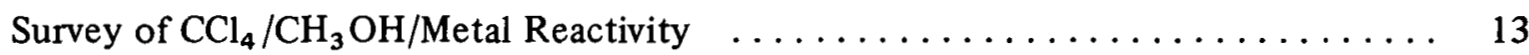

Identification of Products Formed in

$\mathrm{CCl}_{4} / \mathrm{CH}_{3} \mathrm{OH} / \mathrm{Metal}$ Reactions (Other Than $\mathrm{Pu}^{\circ}$ ) $\ldots \ldots \ldots \ldots \ldots \ldots \ldots$

Stimulation of $\mathrm{CCl}_{4} / \mathrm{CH}_{3} \mathrm{OH} / \mathrm{Metal}$ Reactions $\ldots \ldots \ldots \ldots \ldots \ldots \ldots \ldots \ldots \ldots \ldots \ldots \ldots \ldots$

Corrosion Tests of Potential Containment Metals for $\mathrm{CCl}_{4} / \mathrm{CH}_{3} \mathrm{OH} \ldots \ldots \ldots \ldots \ldots$

Plutonium Stripping from $\mathrm{CCl}_{4} / \mathrm{CH}_{3} \mathrm{OH} / \mathrm{Pu}^{\circ}$ Reaction Mixtures $\ldots \ldots \ldots \ldots \ldots \ldots$

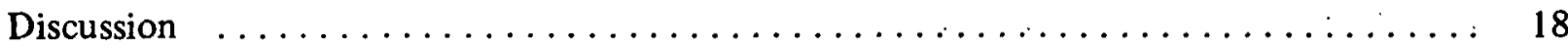

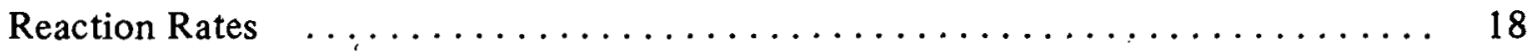

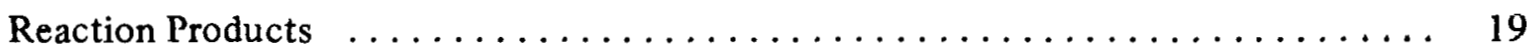

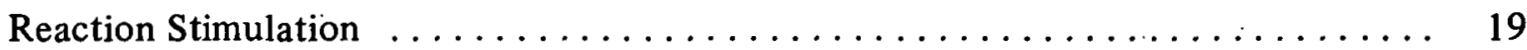




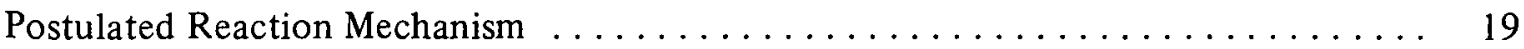

Substitution Reaction ............................ 20

Autoprotolysis-Redox Reactions ......................... 20

Organometallic Intermediates $\ldots \ldots \ldots \ldots \ldots \ldots \ldots \ldots \ldots \ldots \ldots, 20$

Plutonium Metal Hydrogen Gas Reaction $\ldots \ldots \ldots \ldots \ldots \ldots \ldots \ldots .21$

Plutonium(III) to Plutonium(IV) Oxidation Reaction ............. 21

Summation of the Proposed Reaction Sequences $\ldots \ldots \ldots \ldots \ldots \ldots \ldots . \ldots \ldots$

Corrosion of Containment Materials $\ldots \ldots \ldots \ldots \ldots \ldots \ldots \ldots \ldots \ldots \ldots, 22$

Future Investigations $\ldots \ldots \ldots \ldots \ldots \ldots \ldots \ldots \ldots \ldots \ldots \ldots \ldots \ldots \ldots \ldots \ldots \ldots, 22$

References $\ldots \ldots \ldots \ldots \ldots \ldots \ldots \ldots \ldots \ldots \ldots \ldots \ldots \ldots \ldots \ldots \ldots \ldots \ldots \ldots \ldots \ldots \ldots, 22$

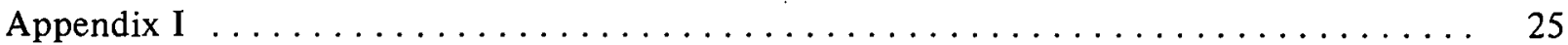

Sclected Data from Unpublished Investigations by S. H. Pitts

Appendix II ..................................... 26

Physical Constants (Properties) of $\mathrm{CCl}_{4}, \mathrm{CH}_{3} \mathrm{OH}$, and $\mathrm{CCl}_{4} / \mathrm{CH}_{3} \mathrm{OH}$

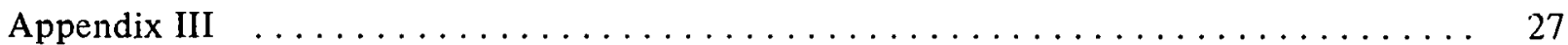

Reagents and Metals Used for This Investigation

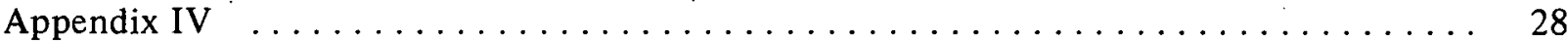

Unpublished Results for Vapor Phase Corrosion of, Metals by Briggs

Appendix V . ...................................... 29

Preliminary Results with Two Other Organic Reaction Systems with Plutonium Metal 


\section{A C K NOW LED G M EN T S}

The author wishes to acknowledge the technical and experimental assistance received from the following: A. L. Johnston and J. W. Berry, laboratory assistance; J. A. Hayden, analytical assistance; C. A. Chambers, interpretation of mass spectral data; and Dr. F. J. Miner, Dr. F. L. Oetting, and C. E. Plock for technical discussions. 


\title{
INVESTIGATION OF THE CARBON
}

\section{TETRACHLORIDE-METHANOL-PLUTONIUM METAL SYSTEM}

\author{
Larry R. Crisler
}

\begin{abstract}
A number of reaction parameters needed to evaluate the feasibility of using the dissolution reaction system, carbon tetrachloride/ methyl alcohol/plutonium metal, for plutonium recovery efforts have been studied. Reaction rates of approximately $13\left[\left(\mathrm{mg} / \mathrm{cm}^{2}\right) / \mathrm{min}\right]$ and 0.14 (moles gas/mole Pu dissolved) at ambient conditions for metal dissolution and reaction offgassing have been determined. The dissolution rate was diminished to approximately $2\left[\left(\mathrm{mg} / \mathrm{cm}^{2}\right) /\right.$ min] at $-26{ }^{\circ} \mathrm{C}$. The heat of reaction for this dissolution was experimentally determined to be $\Delta \mathrm{H}=-205\left(\mathrm{kcal} / \mathrm{mole} \mathrm{Pu}^{\circ}\right.$ consumed $)$. The reaction-induction period normally noted for this reaction system can be altered by adding small amounts of stimulating agents. Organic compounds containing $\beta$-diketone functional groups have been shown to reduce the reaction-induction period to near zero. A number of potential reaction mechanisms are discussed based on a review of the chemistry involved for the reactants.
\end{abstract}

\section{INTRODUCTION}

An unexpected dissolution of plutonium metal by a carbon tetrachloride and methyl alcohol mix ture* was discovered by Pitts. The discovery occurred while investigating means of reducing the hazard encountered in plutonium chips degreasing with $\mathrm{CCl}_{4},{ }^{1-4}$ Using preliminary results determined by Pitts for the $\mathrm{CCl}_{4} / \mathrm{CH}_{3} \mathrm{OH} / \mathrm{Pu}^{\circ}$ reaction system, ${ }^{* *}$ Rocky Flats initiated a program to explore the feasibility of using this solvent mixture for plutonium recovery purposes. Plutonium stripping methods, compatible with Rocky Flats metal production streams, have been developed to remove the plutonium species formed in $\mathrm{CCl}_{4} / \mathrm{CH}_{3} \mathrm{OH} / \mathrm{Pu}^{\circ}$ reaction mixtures.

\footnotetext{
*This mixture will be referred to as $\mathrm{CCl}_{4} / \mathrm{CH}_{3} \mathrm{OH}$ throughout this report.

**These results have not been published; therefore, several important findings of this investigation are summarized in Appendix I.
}

To evaluate $\mathrm{CCl}_{4} / \mathrm{CH}_{3} \mathrm{OH}^{*}$ for plutonium processing efforts, a number of important considerations were reviewed, experimentally investigated, and are discussed in this report. General areas of consideration were as follows:

1.' Physical constants (properties) of individual components and mixture (Appendix II and references therein).

2. Reactive potential of individual components of the $\mathrm{CCl}_{4} / \mathrm{CH}_{3} \mathrm{OH} / \mathrm{Pu}^{\circ}$ reaction system.

3. Reaction parameters pertinent to employment in nonaqueous plutonium recovery efforts.

4. Postulated reaction paths occurring in the $\mathrm{CCl}_{4} / \mathrm{CH}_{3} \mathrm{OH} / \mathrm{Pu}^{\circ}$ reaction system.

\section{REVIEW OF CHEMICAL REACTIVITY FOR $\mathrm{CCl}_{4} / \mathrm{CH}_{3} \mathrm{OH} / \mathrm{Pu}^{\circ}$ REACTION COMPONENTS}

A review of the demonstrated chemical reactivity for each component, and mixtures in the $\mathrm{CCl}_{4} / \mathrm{CH}_{3} \mathrm{OH} / \mathrm{Pu}^{\circ}$ reaction system is presented.

\section{Carbon Tetrachloride}

This organic solvent is generally accepted as relatively "inert" at ambient conditions. Latimer" characterizes the potential reactivity of $\mathrm{CCl}_{4}$ as follows:

"The free energy of $\mathrm{CCl}_{4}$ is small; hence, as an oxidizing agent, it is almost as powerful as chlorine. $4 \mathrm{H}^{+}+4 \mathrm{Cl}^{-}+\mathrm{C}^{\circ}=\mathrm{CCl}_{4}+4 \mathrm{H}^{+}$ $+4 \mathrm{e}^{-}, \mathrm{E}^{\circ}=+1.18$ volts. ${ }^{* *}$ However, at room

*The most reactive mixture found by Pitts, $50-50$ vol \% $\mathrm{CCl}_{4} / \mathrm{CH}_{3} \mathrm{OH}$, was used for this investigation (see Appendix I).

**The convention of the more electropositive elements such as $\mathrm{Na}$ and $\mathrm{K}$ having the more negative potential will be used for electrode potentials. 
temperature, $\mathrm{CCl}_{4}$ is a slow oxidizing agent because of the energy required to break the C-C1 bond. At high temperatures, with reducing agents, very violent reactions may occur, e.g., $\mathrm{CCl}_{4}(1)+\mathrm{N}_{2} \mathrm{H}_{4}(1)=\mathrm{C}^{\circ}+4 \mathrm{HCl}_{(\mathrm{g})}$ $+\mathrm{N}_{2}(\mathrm{~g}), \Delta \mathrm{G}^{\circ}=-100 \mathrm{kcal} . "$

Other examples of $\mathrm{CCl}_{4}$ reactivity include the following:

1. Direct reactions with metals at moderate temperature ${ }^{12,13}$

$$
\begin{aligned}
& \mathrm{Al}^{\circ}+3 \mathrm{CCl}_{4} \frac{\sim 72{ }^{\circ} \mathrm{C}}{\Delta} \mathrm{AlCl}_{3}+\mathrm{C}_{2} \mathrm{Cl}_{6}+\cdot \mathrm{CCl}_{3} \\
& \mathrm{Li}^{\circ}+\mathrm{CCl}_{4} \underset{\text { temp }}{\stackrel{\text { room }}{\longrightarrow} \text { chlorinated organic polymer }}
\end{aligned}
$$

2. Photolysis ${ }^{14}$

$$
\mathrm{CCl}_{4} \stackrel{\mathrm{h} v}{\longrightarrow} \cdot \mathrm{CCl}_{3}+\cdot \mathrm{Cl}
$$

3. Redox reactions ${ }^{15-17}$

$$
\begin{aligned}
\mathrm{CCl}_{4}+8 \mathrm{Cr}(\mathrm{II}) \mathrm{Cl}_{2}+4 \mathrm{HCl} \underset{\text { temp }}{\stackrel{\text { room }}{\longrightarrow}} & \mathrm{CH}_{4} \\
& +8 \mathrm{Cr}(\mathrm{III}) \mathrm{Cl}_{3}
\end{aligned}
$$

4. Ionic reactions ${ }^{18}$

$$
\begin{aligned}
& \mathrm{CCl}_{4} \frac{\mathrm{K}\left(\mathrm{OCH}_{2}-\mathrm{CH}_{3}\right)}{\mathrm{CH}_{3}-\mathrm{CH}_{2}-\mathrm{OH}} \mathrm{CCl}_{3}^{-}+\mathrm{Cl}^{+} \\
& \mathrm{CCl}_{3}^{-} \rightarrow: \mathrm{CCl}_{2}+\mathrm{Cl}^{-} \\
& : \mathrm{CCl}_{2}=\begin{array}{c}
\text { dichlorocarbene (reactive } \\
\text { intermediate species) }
\end{array}
\end{aligned}
$$

5. Hydrolysis ${ }^{11,19}$

$$
\begin{aligned}
& \mathrm{CCl}_{4}+\mathrm{H}_{2} \mathrm{O} \underset{\text { slow }}{\text { room temp }}-\mathrm{Cl}_{2} \mathrm{CO} \text { (phosgene) } \\
& +2 \mathrm{HCl} \\
& \Delta \mathrm{G}^{\circ}=-30.0 \mathrm{kcal}
\end{aligned}
$$

6. Chlorination ${ }^{1,20-22}$

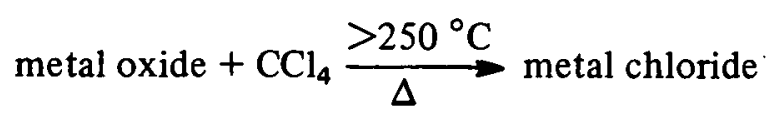

7. Direct chlorination of metals ${ }^{4}$

$$
\mathrm{CCl}_{4}+\mathrm{Pu}^{\circ} \stackrel{\text { high temp }}{\Delta} \mathrm{PuCl}_{3}+--
$$

\section{Methanol (Methyl Alcohol)}

Alcohols, like water, are amphoteric. Methanol exhibits an acid ionization constant slightly less than water. ${ }^{10}$

$$
\begin{aligned}
& \text { Water } \mathrm{pK}_{\mathrm{a}}=14-\mathrm{pK}_{\mathrm{b}} \\
& \text { Methanol } \mathrm{pK}_{\mathrm{a}}=16.8-\mathrm{pK}_{\mathrm{b}}
\end{aligned}
$$

'l'he basicity of water has been determined in methanol; therefore, methanol is more acidic than water. ${ }^{23}$

$$
\begin{aligned}
& \mathrm{CH}_{3} \mathrm{OH}+\mathrm{H}_{3} \mathrm{O}^{+} \stackrel{\mathrm{H}^{+}}{\rightleftharpoons} \mathrm{CH}_{3} \mathrm{OH}_{2}^{+}+\mathrm{H}_{2} \mathrm{O} \\
& \mathrm{K}=\frac{\left[\mathrm{CH}_{3} \mathrm{OH}_{2}^{+}\right]\left[\mathrm{H}_{2} \mathrm{O}\right]}{\left[\mathrm{CH}_{3} \mathrm{OH}\right]\left[\mathrm{H}_{3} \mathrm{O}^{+}\right]}=0.01
\end{aligned}
$$

Other examples of $\mathrm{CH}_{3} \mathrm{OH}$ reactivity include the following:

1. Alcoholate formation 24,25

$$
\mathrm{CH}_{3} \mathrm{OH}+\mathrm{Na}^{\circ} \stackrel{\text { room temp }}{\longrightarrow} \mathrm{Na}\left(\mathrm{OCH}_{3}\right)+1 / 2 \mathrm{H}_{2}
$$

$$
\begin{aligned}
& 3 \mathrm{CH}_{3} \mathrm{OH}+\mathrm{Al}(\mathrm{Hg}) \stackrel{\text { trace }\left(\mathrm{Cl}_{4}\right.}{\longrightarrow} \mathrm{Al}\left(\mathrm{OCH}_{3}\right)_{3} \\
&+3 / 2 \mathrm{H}_{2}
\end{aligned}
$$

$4 \mathrm{CH}_{3} \mathrm{OH}+\mathrm{Ti}^{\circ} \stackrel{120^{\circ} \text { to } 150^{\circ} \mathrm{C}}{\longrightarrow} \mathrm{Ti}\left(\mathrm{OCH}_{3}\right)_{4}$

$$
+2 \mathrm{H}_{2}
$$


2. Substitution reactions ${ }^{26}$.

$$
\mathrm{CH}_{3} \mathrm{OH}+\mathrm{HCl} \rightleftharpoons \mathrm{CH}_{3} \mathrm{Cl}+\mathrm{H}_{2} \mathrm{O}
$$

3. Lucas reagent reaction ${ }^{26}$

$$
\mathrm{CH}_{3} \mathrm{OH}+\mathrm{ZnCl}_{2}+\mathrm{HCl} \rightarrow \mathrm{CH}_{3} \mathrm{Cl}+---
$$

4. Oxidation reactions $\mathrm{s}^{27}$

$$
\mathrm{CH}_{3} \mathrm{OH} \stackrel{[\mathrm{O}]}{\longrightarrow} \mathrm{H}_{2} \mathrm{CO} \stackrel{[\mathrm{O}]}{\longrightarrow} \mathrm{HCO}_{2} \mathrm{H}
$$

$[\mathrm{O}]=\mathrm{CrO}_{3}, \mathrm{H}^{+} ; \mathrm{Cu}^{\circ}$ at $300^{\circ} \mathrm{C} ; \mathrm{KMnO}_{4}$ at $\mathrm{pH} 7$

5. Alcoholysis reaction ${ }^{28}$

$$
\begin{aligned}
& \mathrm{MCl}_{\mathrm{X}}+\mathrm{y} \mathrm{CH}_{3} \mathrm{OH} \rightleftharpoons \mathrm{M}\left(\mathrm{OCH}_{3}\right)_{\mathrm{y}} \mathrm{Cl}_{\mathrm{X}-\mathrm{y}}+\mathrm{y} \mathrm{HCl} \\
& \mathrm{M}=\text { metal }
\end{aligned}
$$

6. Solvent and co-reactant for oxidation reaction $\mathrm{s}^{29-31}$

$$
\begin{aligned}
& \mathrm{Al}^{\circ}+\mathrm{Br}_{2} \stackrel{\mathrm{CH}_{3} \mathrm{OH}}{\longrightarrow} \mathrm{Al}(111)+-- \\
& \mathrm{Be}^{\circ}+\mathrm{Br}_{2} \stackrel{\mathrm{CH}_{3} \mathrm{OH}}{\longrightarrow} \mathrm{Be}(11)+--- \\
& \mathrm{U}^{\circ}+\mathrm{Br}_{2} \stackrel{\mathrm{CH}_{3} \mathrm{OH}}{\longrightarrow} \mathrm{UO}_{2}^{++}+--- \\
& \mathrm{Ta}^{\circ}+\mathrm{Cl}_{2} \stackrel{\mathrm{CH}_{3} \mathrm{OH}}{\longrightarrow} \mathrm{Ta}(\mathrm{V})+---
\end{aligned}
$$

\section{Carbon Tetrachloride and Methanol (Co-Solvent)}

The reactivity of this mixture has been used for a number of practical applications. Although a number of mechanisms have been proposed for specialized reactions, no investigation of the apparent general reactivity of this co-solvent has been accomplished.

1. Direct reaction with metals ${ }^{32-37}$

$$
\begin{aligned}
& \mathrm{CCl}_{4}+\mathrm{Alcohol}+\mathrm{Mg}^{\circ} \rightarrow \mathrm{CHCl}_{3}+--- \\
& \mathrm{CCl}_{4}+\mathrm{CH}_{3} \mathrm{OH}+\mathrm{Zn}^{\circ} \rightarrow \mathrm{CHCl}_{3}+\mathrm{CH}_{2} \mathrm{O}+--- \\
& \mathrm{CCl}_{4}+\mathrm{CH}_{3} \mathrm{OH}+\mathrm{Al}^{\circ} \rightarrow \mathrm{CHCl}_{3}+\mathrm{H}_{2}(\mathrm{~g})+---
\end{aligned}
$$

2. Heat-induced reaction ${ }^{38,}, 39$

$$
2 \mathrm{CCl}_{4}+\mathrm{CH}_{3} \mathrm{OH} \frac{200 \text { to } 210^{\circ} \mathrm{C}}{\Delta(\sim 14 \text { hours })} \mathrm{CHCl}_{3}
$$

$$
+2 \mathrm{HCl}+\mathrm{CH}_{2} \mathrm{O}+---
$$

3. Redox reaction ${ }^{40}$

$$
\begin{aligned}
\mathrm{CCl}_{4}+\mathrm{H}^{++}+2 \mathrm{e}^{-} & \stackrel{\mathrm{CH}_{3} \mathrm{OH}}{\longrightarrow} \mathrm{CHCl}_{3} \\
& +\mathrm{Cl}^{-} \mathrm{E}^{\circ} \mathrm{SCE}^{*}=-0.752 \text { volts }
\end{aligned}
$$

\section{Plutonium Metal}

Plutonium metal acts aś an electropositive metal. ${ }^{41}$ On being oxidized, plutonium can exhibit oxidation states of (III), (IV), (V), and (VI). Halfcell reaction potentials of the (III) and (IV) oxidation states in an aqueous system are as follows: ${ }^{5}$

$$
\begin{aligned}
\mathrm{Pu}^{\circ} & =\mathrm{Pu}^{3+}+3 \mathrm{e}^{-} \mathrm{E}^{\circ}=-2.07 \text { volts } \\
\mathrm{Pu}^{3+} & =\mathrm{Pu}^{4+}+1 \mathrm{e}^{-} \mathrm{E}^{\circ}=+0.97 \text { volts }
\end{aligned}
$$

Other examples of plutonium reactivity include the following:

1. Acid reaction ${ }^{41}$

$$
\begin{aligned}
& \mathrm{Pu}_{(\mathrm{s})}^{\circ}+3 \mathrm{HCl}_{(\mathrm{aq})} \rightarrow \mathrm{PuCl}_{3(\mathrm{aq})}+3 \mathrm{j}_{2} \mathrm{H}_{2}(\mathrm{~g}) \\
& \Delta \mathrm{H}_{\text {solution }}=-141 \frac{\mathrm{kcal}}{\text { mole }}^{(42 \mathrm{a})}
\end{aligned}
$$

2. Hydrogen reaction ${ }^{41}$

$$
\begin{aligned}
\mathrm{Pu}_{(\mathrm{s})}^{\circ}+\mathrm{H}_{2(\mathrm{~g})} \rightarrow \mathrm{PuH}_{2}(\mathrm{~s}) & \Delta \mathrm{H}_{\mathrm{f}_{298}}^{\circ} \\
& =-45.6 \frac{\mathrm{kcal}}{\mathrm{mole}}^{(42 \mathrm{~b}) * *}
\end{aligned}
$$

*SCE = Saturated Calomel Electrode.

**A recent unpublished investigation by Oetting, et al. has found that the previously accepted value $\Delta \mathrm{H}=-33.3(\mathrm{kcal} / \mathrm{mole})$ for plutonium metal hydrogen gas reaction is probably low. The correct value is $-45.6 \pm 3.6(\mathrm{kcal} / \mathrm{mole})$. 
3. Oxidation reaction ${ }^{41}$

$$
\begin{gathered}
\mathrm{Pu}_{(\mathrm{s})}^{\circ}+\mathrm{O}_{2}(\mathrm{~g}) \rightarrow \mathrm{PuO}_{2}(\mathrm{~s}) \\
\Delta \mathrm{H}_{\mathrm{f}_{298}^{\circ}}=-252.870 \frac{\mathrm{kcal}^{(42 a)}}{\text { mole }}
\end{gathered}
$$

This brief review of potential reactivity of the components in the $\mathrm{CCl}_{4} / \mathrm{CH}_{3} \mathrm{OH} / \mathrm{Pu}^{\circ}$ reaction system leads one to an immediate realization that a number of complex reactions could be occurring at ambient conditions. Experiments were conducted to obtain information concerning the following aspects of this reaction system:

1. Plutonium metal reaction rates for the reaction $\mathrm{CCl}_{4} / \mathrm{CH}_{3} \mathrm{OH} / \mathrm{Pu}^{\circ}$ initiated at ambient and subambient temperatures.

2. Off-gas rates from $\mathrm{CCl}_{4} / \mathrm{CH}_{3} \mathrm{OH} / \mathrm{Pu}^{\circ}$ reaction.

3. Maximum plutonium metal alteration in a static $\mathrm{CCl}_{4} / \mathrm{CH}_{3} \mathrm{OH} / \mathrm{Pu}^{\circ}$ reaction system.

4. Heat of reaction, $\mathrm{CCl}_{4} / \mathrm{CH}_{3} \mathrm{OH} / \mathrm{Pu}^{\circ}$.

5. Identification of products formed in $\mathrm{CCl}_{4} / \mathrm{CH}_{3} \mathrm{OH} / \mathrm{Pu}^{\circ}$ reaction.

6. $\mathrm{pH}$ investigations of fresh and aged $\mathrm{CCl}_{4} / \mathrm{CH}_{3} \mathrm{OH}$ mix tures.

7. Survey of $\mathrm{CCl}_{4} / \mathrm{CH}_{3} \mathrm{OH} / \mathrm{metal}$ reactivity.

8. Identification of products formed in $\mathrm{CCl}_{4} / \mathrm{CH}_{3} \mathrm{OH} /$ metal reaction (other than $\mathrm{Pu}^{\circ}$ ).

9. Stimulation of $\mathrm{CCl}_{4} / \mathrm{CH}_{3} \mathrm{OH} /$ metal reactions.

10. Corrosion tests of potential containment construction materials for $\mathrm{CCl}_{4} / \mathrm{CH}_{3} \mathrm{OH}$.

11. Plutonium stripping from $\mathrm{CCl}_{4} / \mathrm{CH}_{3} \mathrm{OH} / \mathrm{Pu}^{\circ}$ reaction mixtures.

12. Plutonium metal reaction rates with other reactive organic solvent mixtures.

\section{EXPERIMENTAL AND RESULTS}

\section{General Experimental Conditions}

Plutonium experiments were conducted at ambient pressure $(\sim 610 \mathrm{~mm} \mathrm{Hg})$ in a nitrogen-gas purged glovebox system. The low flash point $\left(\sim 26^{\circ} \mathrm{C}\right)$ of $\mathrm{CCl}_{4} / \mathrm{CH}_{3} \mathrm{OH}$ demanded the use of an inert atmosphere when conducting experiments with plutonium. The oxygen content of the purged box system was maintained at a level that would not support combustion. A Beckman Model 715 process oxygen monitor indicated an average oxygen content of $<5 \mathrm{vol} \%$. Glass reaction and storage containers were used throughout this investigation. A stainless steel brush was used for cleaning plutunium metal specimens prior to experimentation, cxccpt as noted. Carbon tetrachloride-methanol mixtures were prepared just prior to use, except as noted. Reagents and metals used in this investigation are listed in Appendix III.

\section{Plutonium Metal Reaction Rates with $\mathrm{CCl}_{4} / \mathrm{CH}_{3} \mathrm{OH}$}

'The plutonium metal reaction rates were determined for non-stirred reactions by weight-loss techniques. Metal specimens were cleaned, their surface areàs measured, and the specimens weighed. After a reaction, the metal specimens were rinsed with small portions of fresh $\mathrm{CCl}_{4} / \mathrm{CH}_{3} \mathrm{OH}$, brushed lightly, and reweighed. Weight-loss rates were determined for the following experimental conditions:

\section{(Condition 1) Ambient temperature}

Reaction initiated at 23 to $25^{\circ} \mathrm{C}$

Non-isothermal (no temperature regulation)

(Condition 2) Subambient temperature

$$
\begin{aligned}
& \text { Reaction initiated at }-26^{\circ} \mathrm{C} \\
& \text { Temperature regulated }\left(\mathrm{CCl}_{4} /\right. \text { dry } \\
& \text { ice, constant temperature bath) }
\end{aligned}
$$

The experimental apparatus for reactions utilizing solution volumes of $>10 \mathrm{ml}$ is shown in Figure 1 and consisted of the following components: 


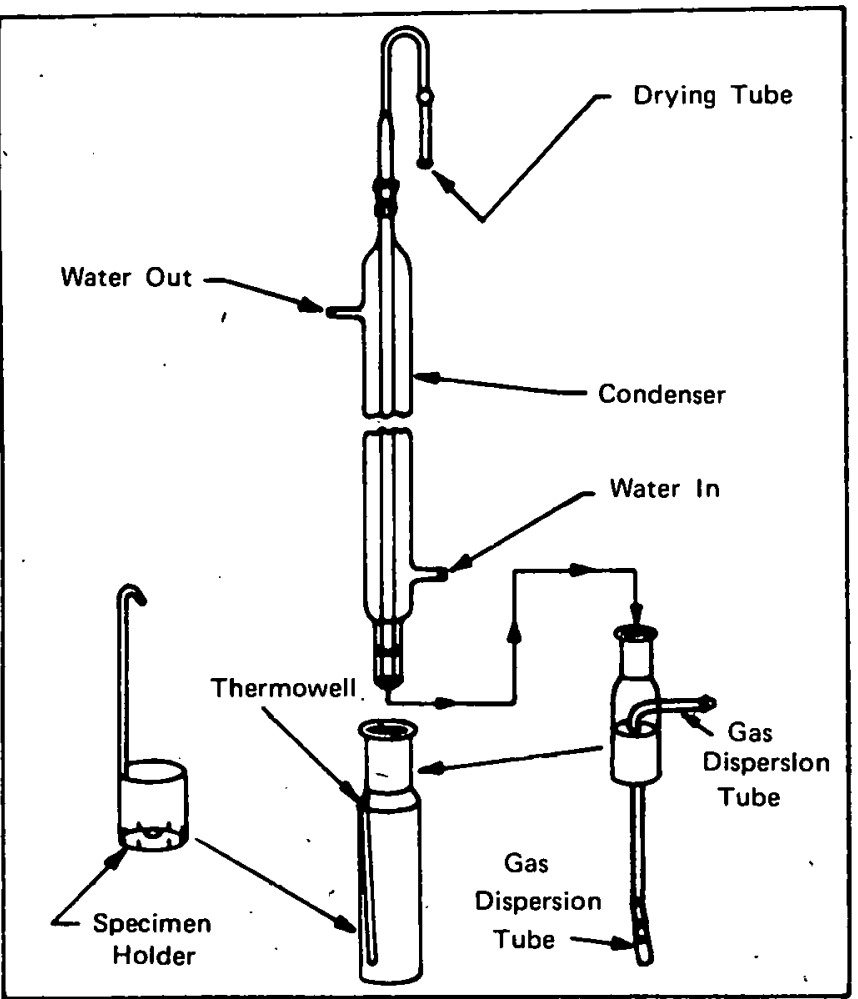

FIGURE 1. Reaction Apparatus for the Determination of Metal Weight Loss.

(1) Reaction vessel ( $\sim 200 \mathrm{ml}$ capacity) equipped with thermowell.

(2) Specimen holder

(3) Gas dispersion tube

(4) Water-cooled condenser

(5) Standard calorimeter thermometer $\left(-10.0\right.$ to $\left.+55.0^{\circ} \mathrm{C}\right)$

The experimental apparatus for reactions utilizing solution volumes of $<10 \mathrm{ml}$ consisted of the following components:

(1) Reaction vessel (1-inch by 3-inch glass vial)

(2) Standard calorimeter thermometer placed in reaction vessel

(3) Water-cooled condenser

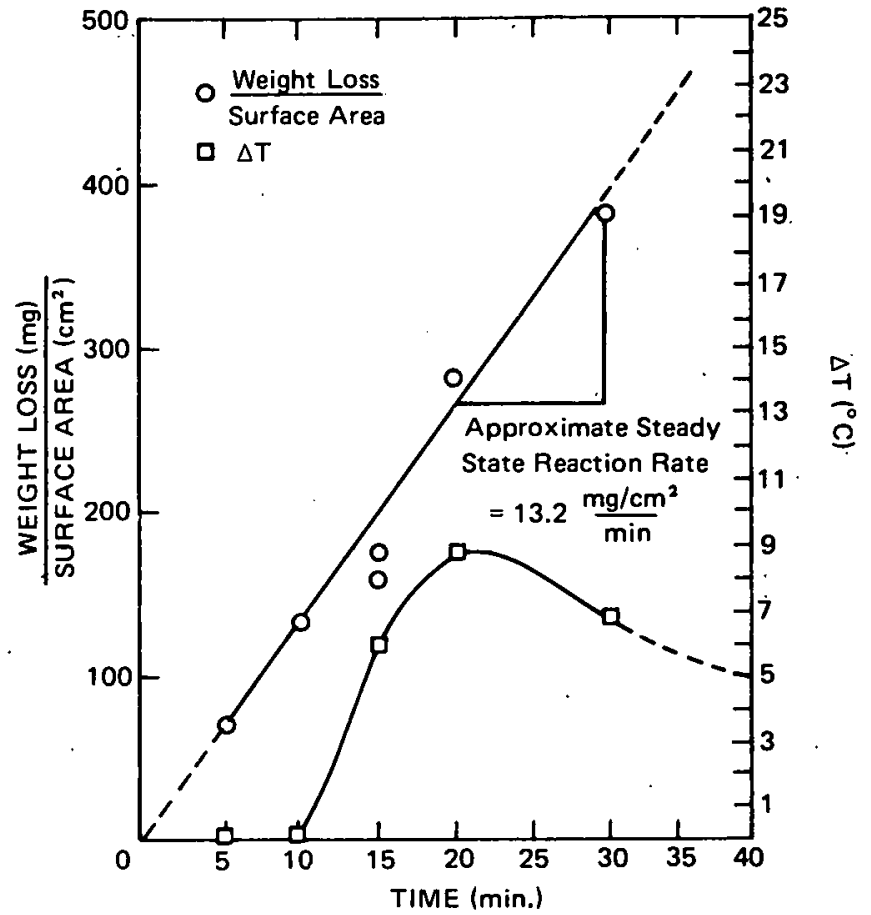

FIGURE 2. Plutonium metal weight loss and reaction medium temperature change for $\mathrm{CCl}_{4} /$ $\mathrm{CH}_{3} \mathrm{OH} / \mathrm{Pu}^{\circ}$ reaction at ratio [volume $\mathrm{CCl}_{4} /$ $\left.\mathrm{CH}_{3} \mathrm{OH}(\mathrm{ml})\right] /\left[\right.$ surface area $\left.\left(\mathrm{cm}^{2}\right)\right]=25$.

Plutonium Metal Reaction Rate at Ambient Conditions (No Temperature Regulation)

Experiment 1a. Condition No. 1: $100 \mathrm{ml}$ $\mathrm{CCl}_{4} / \mathrm{CH}_{3} \mathrm{OH}$, surface area $2 \mathrm{~cm}^{2}$.

Experiment 1b. Condition No. 1: $10 \mathrm{ml}$ $\mathrm{CCl}_{4} / \mathrm{CH}_{3} \mathrm{OH}$, surface area $2 \mathrm{~cm}^{2}$.

$\underline{\text { Results of Experiment } 1 \mathrm{a} \text { and } 1 \mathrm{~b}}$

For dissolvent-surface area ratio, i.e., [volume $\left.\mathrm{CCl}_{4} / \mathrm{CH}_{3} \mathrm{OH}(\mathrm{ml})\right] /\left[\right.$ surface area $\left.\left(\mathrm{cm}^{2}\right)\right]$, profiles for plutonium weight-loss and reaction-temperature changes are illustrated in Figures 2 and 3. These figures reflect volume-surface area ratios of 25 and 5 .

The exothermic nature of the reaction was evident from the $\Delta \mathrm{T}^{\circ} \mathrm{C} /$ time curve. The $\mathrm{Pu}^{\circ}$ reaction rate 


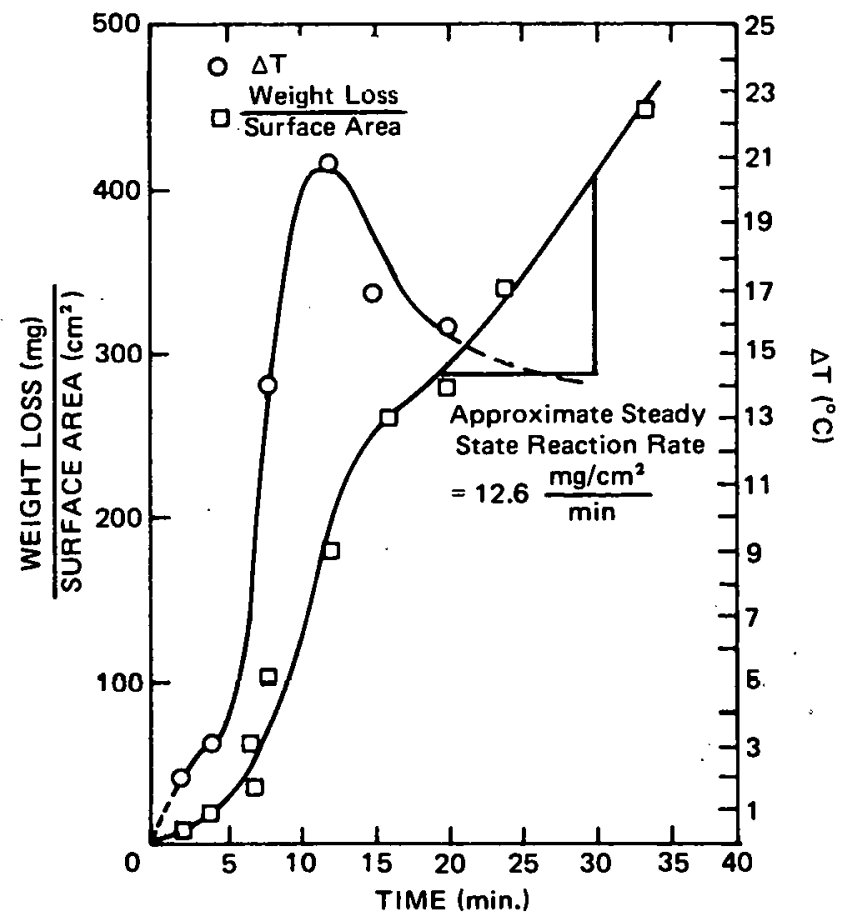

FIGURE 3. Plutonium metal weight loss and reaction medium temperature change for $\mathrm{CCl}_{4} /$ $\mathrm{CH}_{3} \mathrm{OH} / \mathrm{Pu}^{\circ}$ reaction at ratio [volume $\mathrm{CCl}_{4}$ / $\left.\mathrm{CH}_{3} \mathrm{OH}(\mathrm{ml})\right] /\left[\right.$ surface area $\left.\left(\mathrm{cm}^{2}\right)\right]=5$.

for the 25 ratio was nearly linear at $13.2\left(\mathrm{mg} / \mathrm{cm}^{2}\right) /$ $\mathrm{min}$. "The $\mathrm{S}$-shaped rate curve shown for the 5 ratio was caused by rate acceleration, which was brought about by the exothermic reaction.

After 20 minutes, the reaction rate in this system was also nearly linear at $12.6\left(\mathrm{mg} / \mathrm{cm}^{2}\right) / \mathrm{min}$.

Plutonium Metal Reaction Rate at Subambient Conditions (Temperature Regulated)

Experiment 1c: Condition No. 2: $100 \mathrm{ml}$ $\mathrm{CCl}_{4} / \mathrm{CH}_{3} \mathrm{OH}$, surface area $2 \mathrm{~cm}^{2}$.

\section{Results of Experiment 1c}

Figure 4 shows the plutonium weight loss rate at subambient temperature conditions. The ratio [volume $\mathrm{CCl}_{4} / \mathrm{CH}_{3} \mathrm{OH}(\mathrm{ml})$ ] /[ surface area $\left(\mathrm{cm}^{2}\right)$ ]

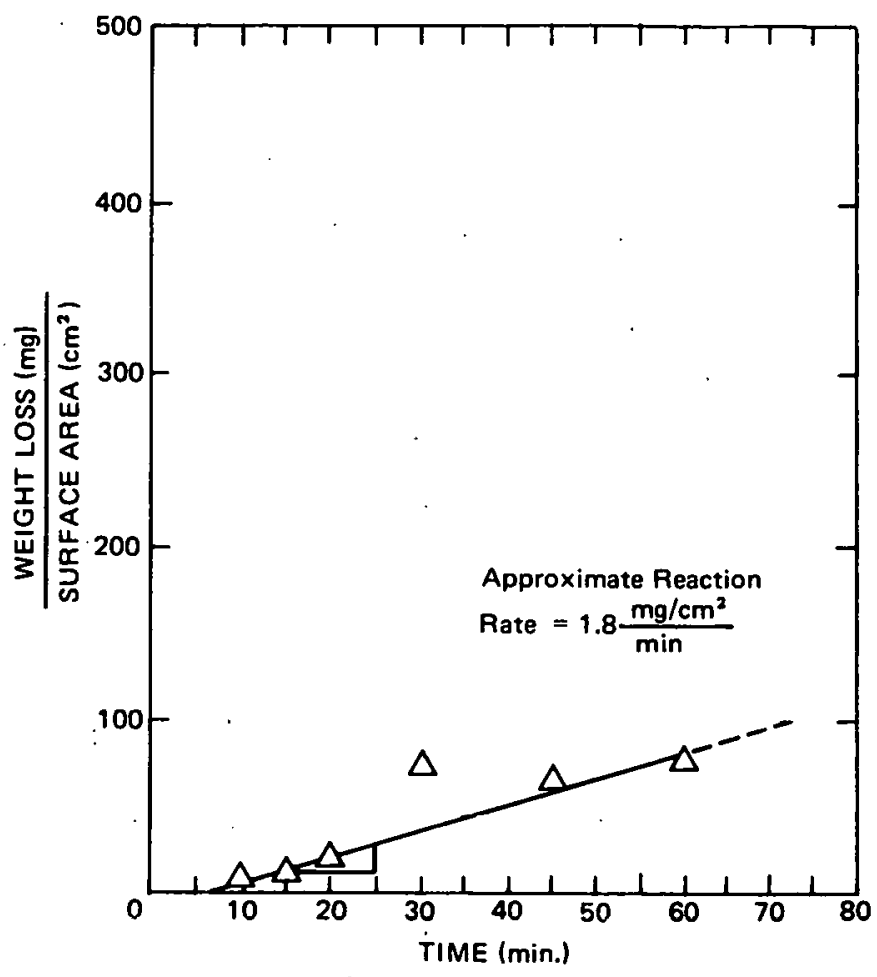

FIGURE 4. Plutonium Metal Weight Loss for Subambient $\left(-26{ }^{\circ} \mathrm{C}\right) \mathrm{CCl}_{4} / \mathrm{CH}_{3} \mathrm{OH} / \mathrm{Pu}^{\circ}$ Reaction. The Reaction Ratio Was 50.

was 50. A reaction induction period of 8 to 10 minutes was observed and a linear reaction rate of $1.8\left(\mathrm{mg} / \mathrm{cm}^{2}\right) / \mathrm{min}$ determined. The subambient reaction rate is approximately seven times less than ambient reaction rate.

\section{Off-Cas Ratcs from $\mathrm{CCl}_{4} / \mathrm{CH}_{3} \mathrm{OH} / \mathrm{Pu}^{\circ}$ Reaction}

The off-gas rates were obtained by monitoring liquid $\left(\mathrm{C}\left(\mathrm{I}_{4} / \mathrm{C}: \mathrm{H}_{3} \mathrm{O}\right) \mathrm{H}\right)$ displacement in the apparatus shown in Figures 5 and 6 . The large system (Figure 5) contained a $400-\mathrm{ml}, \mathrm{CCl}_{4} / \mathrm{CH}_{3} \mathrm{OH}$ solution at reaction initiation. The small apparatus contained a $200-m l$ solution at reaction initiation. The quantities of off-gases were calculated using an Ideal Gas Law Approximation.

Experiment 2a. Condition No. 1: $400 \mathrm{ml}$ $\mathrm{CCl}_{4} / \mathrm{CH}_{3} \mathrm{OH}$, surface area $2 \mathrm{~cm}^{2}$. 


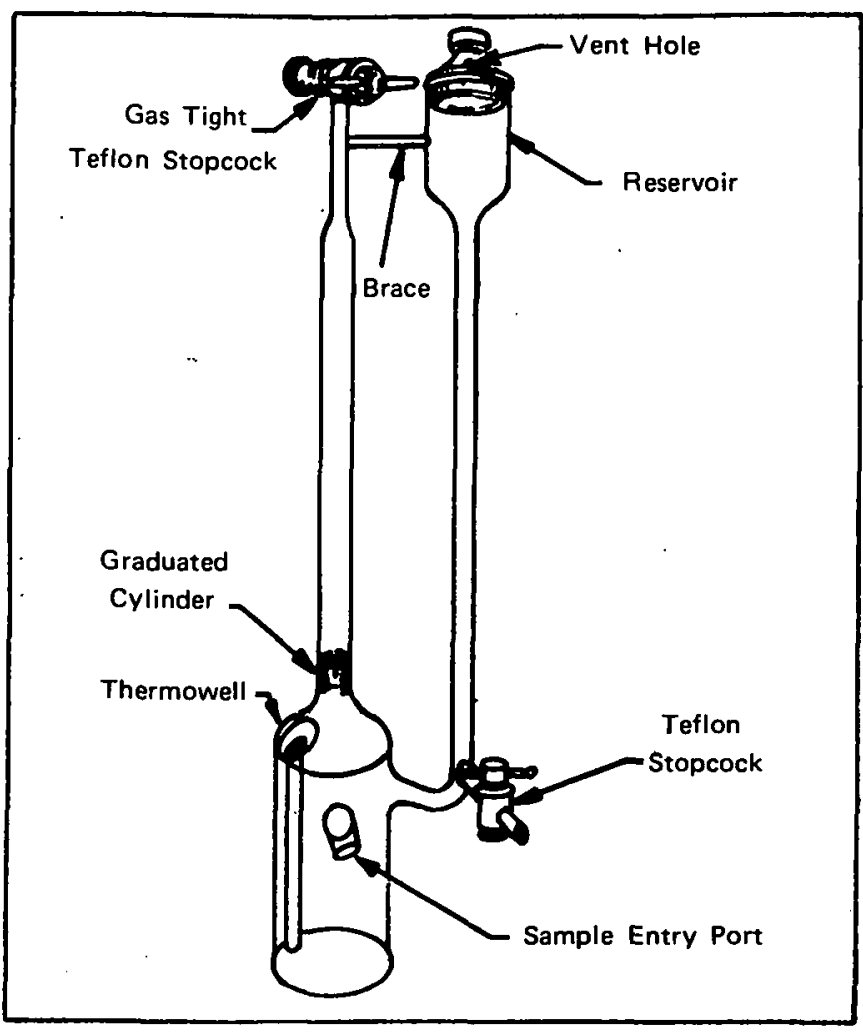

FIGURE 5. Reaction Apparatus for Monitoring Off-Gas Rate of $\mathrm{CCl}_{4} / \mathrm{CH}_{3} \mathrm{OH} / \mathrm{Pu}^{\circ}$ Reaction (400-ml solution).

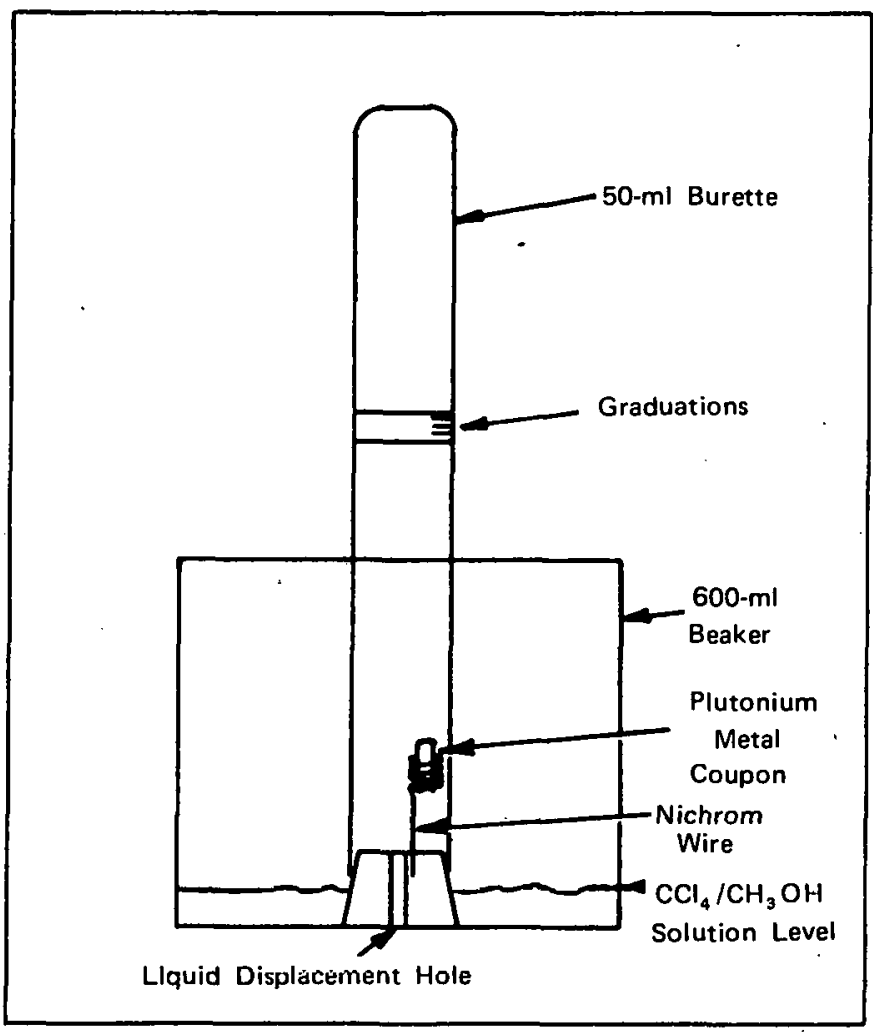

FIGURE 6. Reaction Apparatus for Monitoring Off-Gas Rate of $\mathrm{CCl}_{4} / \mathrm{CH}_{3} \mathrm{OH} / \mathrm{Pu}^{\circ}$ Reaction (200-ml solution).
Experiment 2b. Condition No. 1: $200 \mathrm{ml}$ $\mathrm{CCl}_{4} / \mathrm{CH}_{3} \mathrm{OH}$, surface area $1 \mathrm{~cm}^{2}$.

Experiment 2c. Condition No. 1: $200 \mathrm{ml}$ $\mathrm{CCl}_{4} / \mathrm{CH}_{3} \mathrm{OH}$, surface area $2 \mathrm{~cm}^{2}$.

Experiment 2d. Condition No. 1: $200 \mathrm{ml}$ $\mathrm{CCl}_{4} / \mathrm{CH}_{3} \mathrm{OH}$; surface area $2.5 \mathrm{~cm}^{2}$.

\section{Results of Experiments 2a through 2d}

Figure 7 shows off-gas rate at ambient isothermal and ambient non-isothermal $\left(\Delta \mathrm{T} \sim 6^{\circ} \mathrm{C}\right)$ conditions. The non-isothermal reactions produced off-gases at a faster rate than isothermal reactions, as one would predict. For comparison, Figure 8 shows the rate of metal consumption and the off-gassing rate. These rates differ by approximately one order of magnitude. The major off-gas detected was hydrogen. Several liquid products that exhibit high vapor pressures at ambient conditions (i.e., $\mathrm{CHCl}_{3}, \mathrm{CH}_{2} \mathrm{Cl}_{2}$, and $\mathrm{CH}_{3} \mathrm{Cl}$ ) were also de tected.

Maximum Plutonium Metal Alteration in a Static $\mathrm{CCl}_{4} / \mathrm{CH}_{3} \mathrm{OH} / \mathrm{Pu}^{\circ}$ Reaction System

Maximum plutonium metal alteration by a fixed volume of $\mathrm{CCl}_{4} / \mathrm{CH}_{3} \mathrm{OH}$ was investigated. $\mathrm{A}$ maximized bulk metal* reaction system was simulated by utilizing a reactive component ratio equaling $1.8{ }^{* *}$

*It was considered highly probable that as the metal surface area-unit weight became large (i.e. metal fines, lathe turnings, powdered metal, and so forth), hazardous "run-away" reactions would occur.

**A ratio $[$ volume reactant $(\mathrm{ml})] /\left[\right.$ surface area $\left.\left(\mathrm{cm}^{2}\right)\right]=1.8$. 


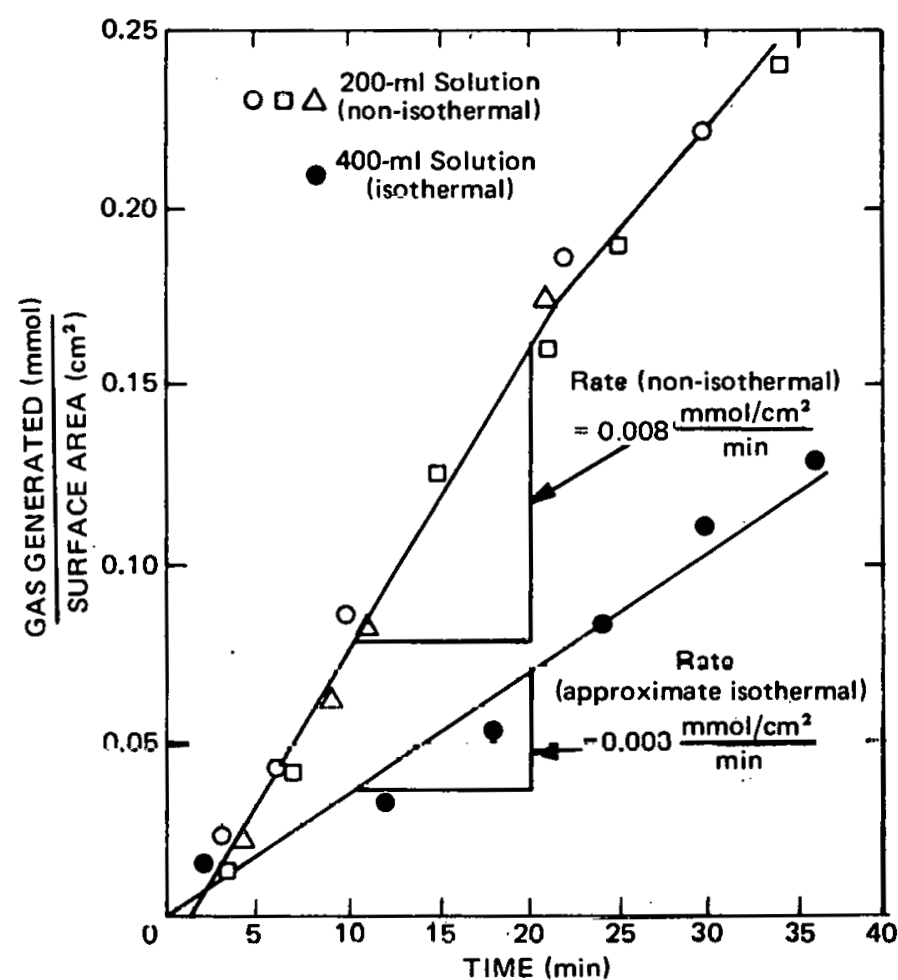

FIGURE 7. Off-Gas Formation for $\mathrm{CCl}_{4} / \mathrm{CH}_{3} \mathrm{OH} / \mathrm{Pu}^{\circ}$ Reactions.

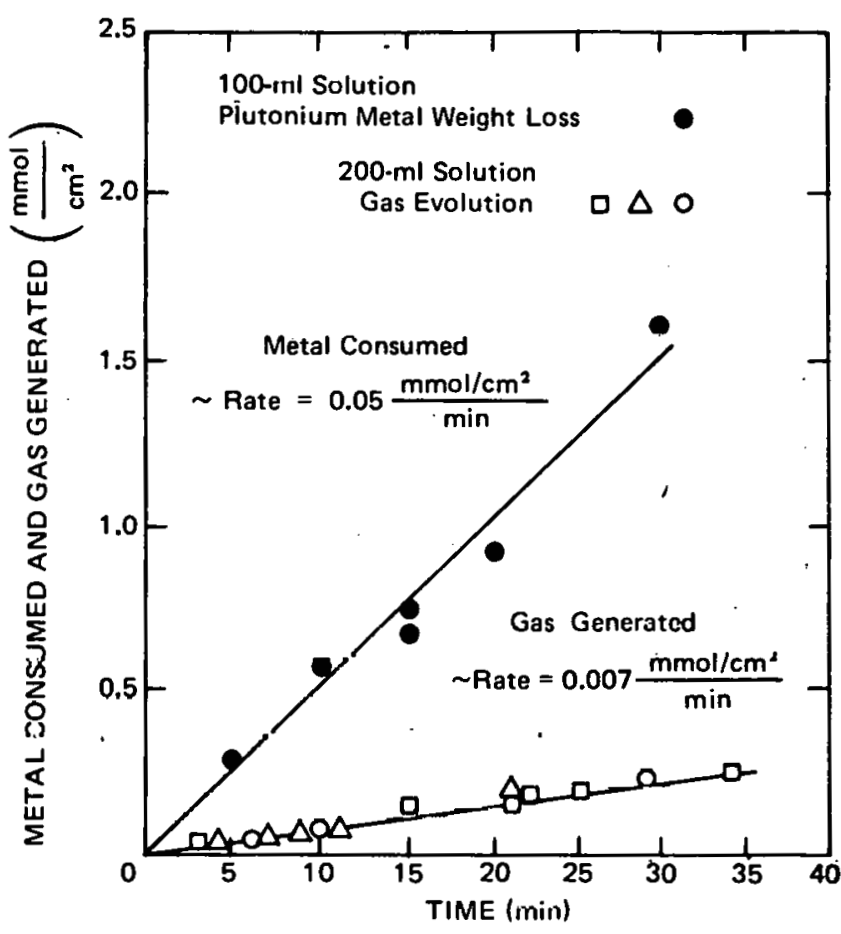

FIGURE 8. Plutonium Metal Consumed Compared with Off-Gases Generated for $\mathrm{CCl}_{4} / \mathrm{CH}_{3} \mathrm{OH} / \mathrm{Pu}^{\circ}$ Reactions.

\section{Results of Experiments $3 a$ and $3 b$}

Figure 9 shows the reaction rate changes encountered in long-term exposure of plutonium metal with $\mathrm{CCl}_{4} / \mathrm{CH}_{3} \mathrm{OH}$. At least three general dcgrees of weight loss rates were evident:

Rate 1 (reaction time 0 to 0.2 day) $=1500(\mathrm{~g} / 1) /$ day Kate 2 (reaction time 0.2 to 2 days) $=61(\mathrm{~g} / \mathrm{l}) /$ day Rate 3 (reaction time 2 to 16 days) $=5(\mathrm{~g} / 1) /$ day

Figure 10 compares the initial temperature change profile of this system (ratio 1.8) with the ratio change systemis of 25 and 5. Sufficient heat was generatcd after 10 minutes reaction period to cause the reaction mixture (ratio 1.8 ) to boil (B.P. $\sim 52{ }^{\circ} \mathrm{C}$ ), but this condition did not persist. After a reaction 


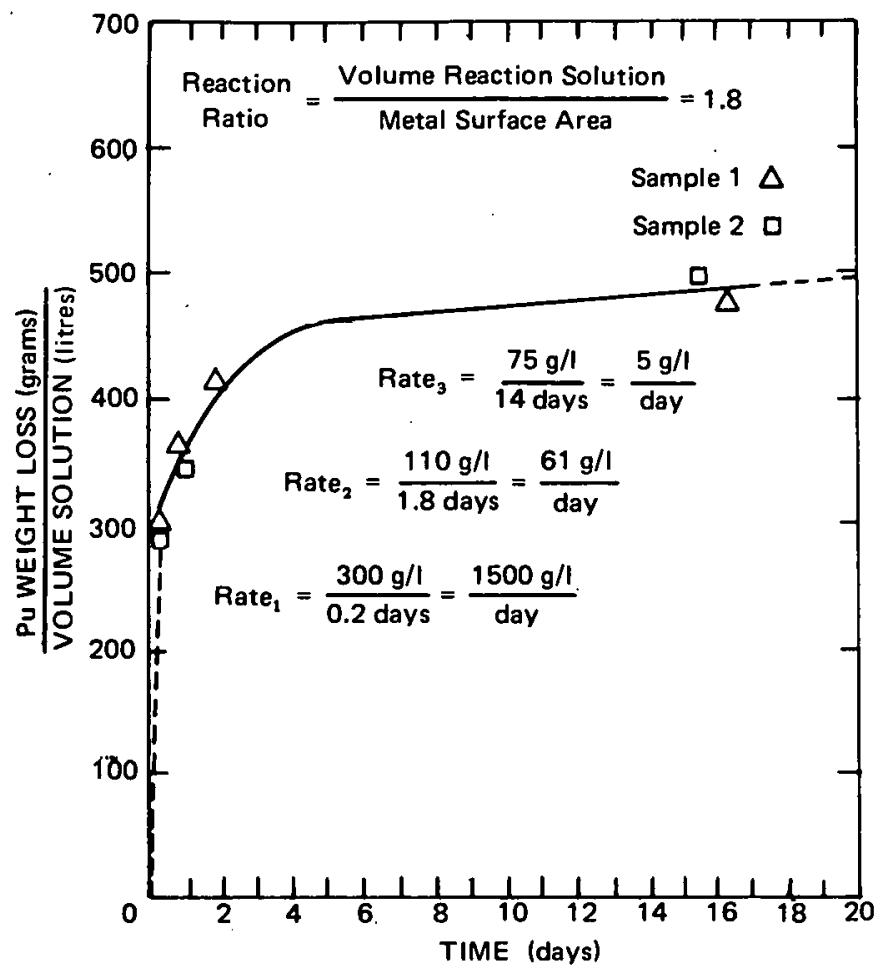

FIGURE 9. Plutonium Metal Weight Loss for $\mathrm{CCl}_{4} / \mathrm{CH}_{3} \mathrm{OH} / \mathrm{Pu}^{\circ}$ Reaction at Ratio 1.8 .

period of 30 minutes, the system temperature had decreased to approximately $+8{ }^{\circ} \mathrm{C}$ above ambient. The reaction mixture temperature had returned to near ambient after 30 additional minutes (total $=60$ minutes reaction).

\section{Heat of Reaction, $\mathrm{CCl}_{4} / \mathrm{CH}_{3} \mathrm{OH} / \mathrm{Pu}^{\circ}$}

A simple calorimeter (Figure 11) was designed to determine the amount of heat liberated during the reaction of plutonium metal with $\mathrm{CCl}_{4} / \mathrm{CH}_{3} \mathrm{OH}$. A similar, simplified system has been adequately described in the literature..$^{43-45}$ A standard procedure ${ }^{45}$ was used to obtain the heat capacity of the calorimeter. The experiments were performed in an open-faced hood equipped with a guillotinetype safety shield. The reaction mixture and calorimeter water bath were stirred using a magnetic stir plate and Teflon $\otimes$-covered stir bars. The

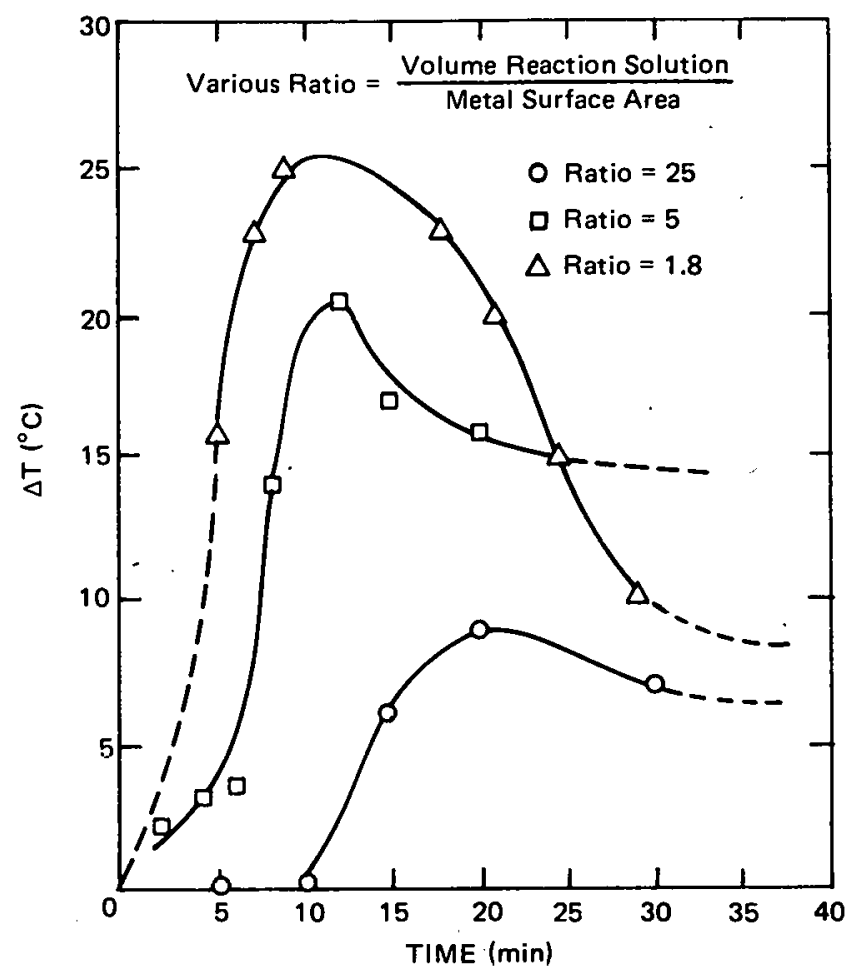

FIGURE 10. Comparison of Reaction Medium Temperature Changes in Reactions of Various [volume $\mathrm{CCl}_{4} / \mathrm{CH}_{3} \mathrm{OH}$ ]/[surface area] Ratios. reliability of the system was checked by the reaction of magnesium metal with hydrochloric acid.

\section{Experiment 4}

a. Heat capacity of calorimeter (Cp).

1. $98.5 \mathrm{~g}$ water at $24.61^{\circ} \mathrm{C}$ $95.3 \mathrm{~g}$ water at $31.50^{\circ} \mathrm{C}$

2. $99.2 \mathrm{~g}$ water at $26.30^{\circ} \mathrm{C}$ $94.0 \mathrm{~g}$ water at $33.55^{\circ} \mathrm{C}$

b. Reliability check with $\mathrm{Mg}^{\circ} / \mathrm{HCl}$ reaction

1. $0.0509 \mathrm{~g} \mathrm{Mg}^{\circ}+8.7 \mathrm{~g} \mathrm{~N} \mathrm{HCl}$

2. $0.0544 \mathrm{~g} \mathrm{Mg}^{\circ}+8.9 \mathrm{~g} 1 \mathrm{~N} \mathrm{HCl}$ 
3. $0.0436 \mathrm{~g} \mathrm{Mg}^{\circ}+9.5 \mathrm{~g} 1 \mathrm{~N} \mathrm{HCl}$

4. $0.0507 \mathrm{~g} \mathrm{Mg}^{\circ}+10.1 \mathrm{~g} 1 \mathrm{~N} \mathrm{HCl}$

c. Heat of reaction $\mathrm{CCl}_{4} / \mathrm{CH}_{3} \mathrm{OH} / \mathrm{Pu}^{\circ}$

1. $0.3747 \mathrm{~g} \mathrm{Pu}^{\circ}+8.2 \mathrm{~g} \mathrm{CCl}_{4}+4.1 \mathrm{~g} \mathrm{CH}_{3} \mathrm{OH}$

2. $0.4854 \mathrm{~g} \mathrm{Pu}^{\circ}+8.2 \mathrm{~g} \mathrm{CCl}_{4}+4.1 \mathrm{~g} \mathrm{CH}_{3} \mathrm{OH}$

Results of Experiments 4 (a, b, c)

The heat capacity of the calorimeter was calculated as previously described. ${ }^{45}$ Part (a) of Table 1 shows several typical determinations for this value. The average heat capacity of this system was found to be $20.3 \mathrm{cal} /{ }^{\circ} \mathrm{C}$. The reliability of the calorimeter system was checked using the reaction of magnesium metal with hydrochloric acid $(\Delta \mathrm{H}=111.3$ $\mathrm{kcal} / \mathrm{mole}){ }^{46}$ A value of $112.1 \pm 3.0 \mathrm{kcal} / \mathrm{mole}$ was determined by this calorimetric system [Table 1, part (b)] . A relative error of $0.72 \%$ from the reported value indicates a reasonably reliable heat-of-reaction calorimeter system. The heat-of-reaction of $\mathrm{CCl}_{4} / \mathrm{CH}_{3} \mathrm{OH} / \mathrm{Pu}^{\circ}$ was found to be $205.4 \mathrm{kcal} / \mathrm{mole}$ [Table 1, part (c)] .

\section{Identification of Products Formed in $\mathrm{CCl}_{4} / \mathrm{CH}_{3} \mathrm{OH} / \mathrm{Pu}^{\circ}$ Reaction}

The products formed in the reaction of $\mathrm{CCl}_{4} / \mathrm{CH}_{3} \mathrm{OH} /$ $\mathrm{Pu}^{\circ}$ were investigated by several analytical techniques that are described below.

Electronic Spectra of Plutonium Species Formed in $\mathrm{CCl}_{4} / \mathrm{CH}_{3} \mathrm{OH} / \mathrm{Pu}^{\circ}$ Reaction Mixtures

\section{Experiment 5a}

A Carey Model 14 spectrometer was used to record the electronic spectra ( 400 to $1000 \mathrm{~nm}$ ) of the plutonium species present during reaction. A plutonium metal specimen $(0.0174 \mathrm{~g})$ was reacted with $3.0 \mathrm{ml} \mathrm{CCl}_{4} / \mathrm{CH}_{3} \mathrm{OH}$ in a $1.0-\mathrm{cm}$ Pyrex® cell. Spectra were recorded at 15 -minute, 4 -hour, and 16-hour intervals after the reaction was initiated.

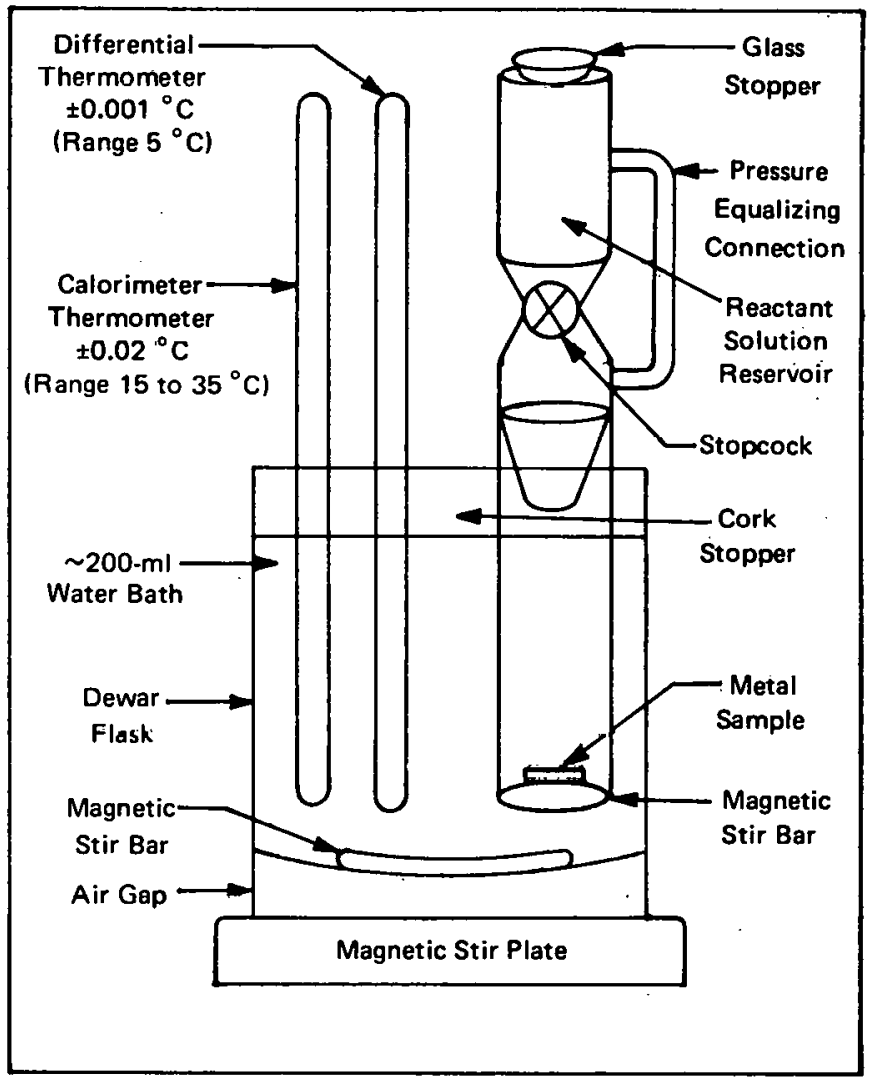

FIOURE 11. IIeat-uf-Reaction Cálurineter.

\section{Results of Experiment 5a}

Figure 12 shows the electronic spectra of the plutonium species existing at several reaction-time intervals. Brief descriptions of the mixtures at sampled times follows:

Reaction initiation plus 15 minutes-plutonium metal was continuing to react with $\mathrm{CCl}_{4} / \mathrm{CH}_{3} \mathrm{OH}$. The blue solution was clear.

Reaction initiation plus 4 hours-the plutonium metal was completely consumed. A brown precipitate was evident. The greenish-blue solution was clear. 
TABLE 1. Heat of $\mathrm{CCl}_{4} / \mathrm{CH}_{3} \mathrm{OH} / \mathrm{Pu}^{\circ}$ Reaction.

(a) Cp calorimeter (heat capacity)*

\begin{tabular}{|c|c|c|c|c|c|c|c|c|}
\hline Determination & $\begin{array}{l}\text { Weight Cold } \\
\mathrm{H}_{2} \mathrm{O}\left(\mathrm{W}_{2}\right)^{*}(\mathrm{~g})\end{array}$ & $\begin{array}{l}\text { Weight Warm } \\
\mathrm{H}_{2} \mathrm{O}\left(\mathrm{W}_{1}\right)^{*}(\mathrm{~g})\end{array}$ & $\begin{array}{l}\Delta \mathrm{T}_{2} \\
\left({ }^{\circ} \mathrm{C}\right)\end{array}$ & $\begin{array}{l}\Delta \mathrm{T}_{1} \\
\left({ }^{\circ} \mathrm{C}\right)\end{array}$ & $\begin{array}{l}\Delta \mathrm{H}_{1} \\
\text { (cal) }\end{array}$ & $\begin{array}{l}\Delta \mathrm{H}_{2} \\
(\mathrm{cal})\end{array}$ & $\begin{array}{c}\mathrm{Cp}_{\mathrm{cal}} \\
\text { (cal/deg) }\end{array}$ & $\begin{array}{l}\text { Avg } \mathrm{Cp}_{\mathrm{cal}} \\
\text { (cal/deg) }\end{array}$ \\
\hline 1 & 98.5 & 95.3 & 3.10 & 3.79 & 361.2 & 305.4 & 18.0 & 20.3 \\
\hline 2 & 99.2 & 94.0 & 3.16 & 4.09 & 384.5 & 313.5 & 22.5 & \\
\hline
\end{tabular}

(b) Reliability check of Calorimeter $\left(\mathrm{Mg}^{\circ}+\mathrm{HCl}\right.$ reaction)

\begin{tabular}{|c|c|c|c|c|c|c|}
\hline Determination & $\begin{array}{c}\text { Weight } \mathrm{Mg}^{\circ} \\
\text { (g) }\end{array}$ & $\begin{array}{c}\text { Weight IN HCl } \\
(\mathrm{g})\end{array}$ & $\begin{array}{c}\text { Total Heat Evolved } \\
\Delta \mathrm{H}_{\mathrm{t}} \text { (cal) }\end{array}$ & $\begin{array}{c}\Delta \mathrm{H}_{\mathrm{t}} / \mathrm{g} \mathrm{Mg}^{\circ} \\
\quad(\mathrm{cal} / \mathrm{g})\end{array}$ & $\begin{array}{c}\Delta \mathrm{H}_{\mathrm{t}} / \text { mole } \mathrm{Mg}^{\circ} \\
(\mathrm{kcal} / \mathrm{mole})\end{array}$ & $\begin{array}{c}\text { Avg } \Delta \mathrm{H} \\
(\mathrm{kcal} / \mathrm{mole})\end{array}$ \\
\hline 1 & 0.0509 & 8.7 & 228.2 & 4483 & 109.0 & \\
\hline 2 & 0.0544 & 8.9 & 255.7 & 4701 & 114.2 & 112.0 \\
\hline 3 & 0.0436 & 9.5 & 205.9 & 4722 & 114.7 & \\
\hline 4 & 0.0507 & 10.1 & 229.4 & 4525 & 110.0 & \\
\hline
\end{tabular}

(c) Heat of reaction $\mathrm{CCl}_{4} / \mathrm{CH}_{3} \mathrm{OH} / \mathrm{Pu}^{\circ}$

\begin{tabular}{|c|c|c|c|c|c|c|c|}
\hline Determination & $\begin{array}{c}\text { Weight } \mathrm{Pu}^{\circ} \\
(\mathrm{g})\end{array}$ & $\begin{array}{l}\text { Weight } \\
\mathrm{CCl}_{4}(\mathrm{~g})\end{array}$ & $\begin{array}{c}\text { Weight } \\
\mathrm{CH}_{3} \mathrm{OH}(\mathrm{g})\end{array}$ & $\begin{array}{c}\text { Total Heat Evolved } \\
\Delta \mathrm{H}_{\mathrm{t}} \text { (cal) }\end{array}$ & $\begin{array}{c}\Delta \mathrm{H}_{\mathrm{t}} / \mathrm{g} \mathrm{Pu}^{\circ} \\
\quad(\mathrm{cal} / \mathrm{g})\end{array}$ & $\begin{array}{c}\Delta \mathrm{H}_{\mathrm{t}} / \mathrm{mole} \mathrm{Pu}^{\circ} \\
(\mathrm{kcal} / \mathrm{mole})\end{array}$ & Avg $\Delta H$ \\
\hline 1 & 0.3747 & 8.2 & 4.1 & 336.4 & 897.7 & 214.7 & 205.4 \\
\hline 2 & 0.4854 & 8.2 & 4.1 & 397.9 & 81.9 .7 & 196.0 & \\
\hline
\end{tabular}

*Standardized notations from Reference 45.

Reaction initiation plus 16 hours-the precipitate had completely dissolved. The greenishbrown solution was clear.

The species at 15 minutes were similar to aqueous Pu(III). ${ }^{47}$ After 4 hours, the major species present were similar to aqueous-Pu(IV) ${ }^{47}$ with a significant concentration effect observed when the precipitate formed (4-hour observation) dissolved (4 to 16 hours).

\section{Product Precipitated from $\mathrm{CCl}_{4} / \mathrm{CH}_{3} \mathrm{OH} / \mathrm{Pu}^{\circ}$ Reaction Mixtures}

\section{Experiment $5 \mathrm{~b}$}

Solid plutonium products were formed by the addition of the following precipitating reagents to
$\mathrm{CCl}_{4} / \mathrm{CH}_{3} \mathrm{OH} / \mathrm{Pu}^{\circ}$ reaction mixtures at different reaction-time intervals. These products were then analyzed by standard powder $\mathrm{X}$-ray diffraction techniques. The X-ray diffraction patterns obtained were compared with reported American Society for Testing and Materials (ASTM) and literature references for identification. Oxidation states of the plutonium species present in the $\mathrm{CCl}_{4} / \mathrm{CH}_{3} \mathrm{OH} / \mathrm{Pu}^{\circ}$ reaction mixture were deduced from the precipitated compounds formed.

(1) Between 30 and 60 minutes reaction Reaction products $+98 \% \mathrm{HCO}_{2} \mathrm{H}$ (formic acid)

(2) Between 30 and 180 minutes reaction

$$
\text { Reaction product }+48 \% \mathrm{HF}^{*}
$$

*The HF was partially dehydrated by using 2,2-dimethoxypropane in an effort to produce arhiydrous $\mathrm{PuF}_{3}$. 
(3) At 16 hours reaction

$$
\begin{aligned}
& \text { Reaction product }+\mathrm{NH}_{4} \mathrm{~F} \cdot \mathrm{HF} \\
& \underset{\text { supersaturated }}{\stackrel{\text { solution in methanol }}{\longrightarrow}}
\end{aligned}
$$

(4) At 144 hours reaction

Reaction product $+48 \% \mathrm{HF} \longrightarrow$

\section{Results of Experiment $5 \mathrm{~b}$}

Table 2 shows the plutonium precipitates formed at different reaction-mixture contact times. With the exception of formic acid, the precipitating agents removed ca. $100 \%$ of the colored plutonium species. The addition of formic acid formed ca. $30 \%$ plutonium(11I) formate. ${ }^{48}$ An intense bluegreen solution remained above the plutonium(III) formate precipitate. The plutonium compounds formed, indicate that the $\mathrm{Pu}(\mathrm{III})$ oxidation state predominates in $\mathrm{CCl}_{4} / \mathrm{CH}_{3} \mathrm{OH} / \mathrm{Pu}^{\circ}$ reaction mixtures for periods $\leqslant 180$ minutes. After 16 hours, the plutonium(IV) oxidation state predominates. Although it was not established by this investigation, a changing mix ture of $\mathrm{Pu}$ (III) to $\mathrm{Pu}$ (IV) oxidation state species would be predicted for the interim period ( 180 minutes to 16 hours). When precipitated, reaction mix tures stored for several months still exhibit the plutonium(IV) oxidation state.

\section{pH Investigation of Fresh and Aged $\mathrm{CCl}_{4} / \mathrm{CH}_{3} \mathrm{OH}$ Mixtures}

The $\mathrm{pH}$ range values of aged and freshly mixed $\mathrm{CCl}_{4} / \mathrm{CH}_{3} \mathrm{OH}$ were investigated using colored $\mathrm{pH}$ indicators. The aged mixture was protected from water vapor by an Aquasorb $\otimes$ tube. The mixture samples $(\sim 10 \mathrm{ml})$ were placed in 1 -inch by 3 -inch glass vials. Indicator powders ( 1 to $10 \mu \mathrm{g}$ ) were added, and the mixtures shaken. The neutral $\mathrm{pH}$ range color for each indicator was determined in anhydrous methanol.

\section{Experiment 6}

\section{Indicator powders}

$$
\text { (1) } \rho \text {-naphtholbenzein }
$$

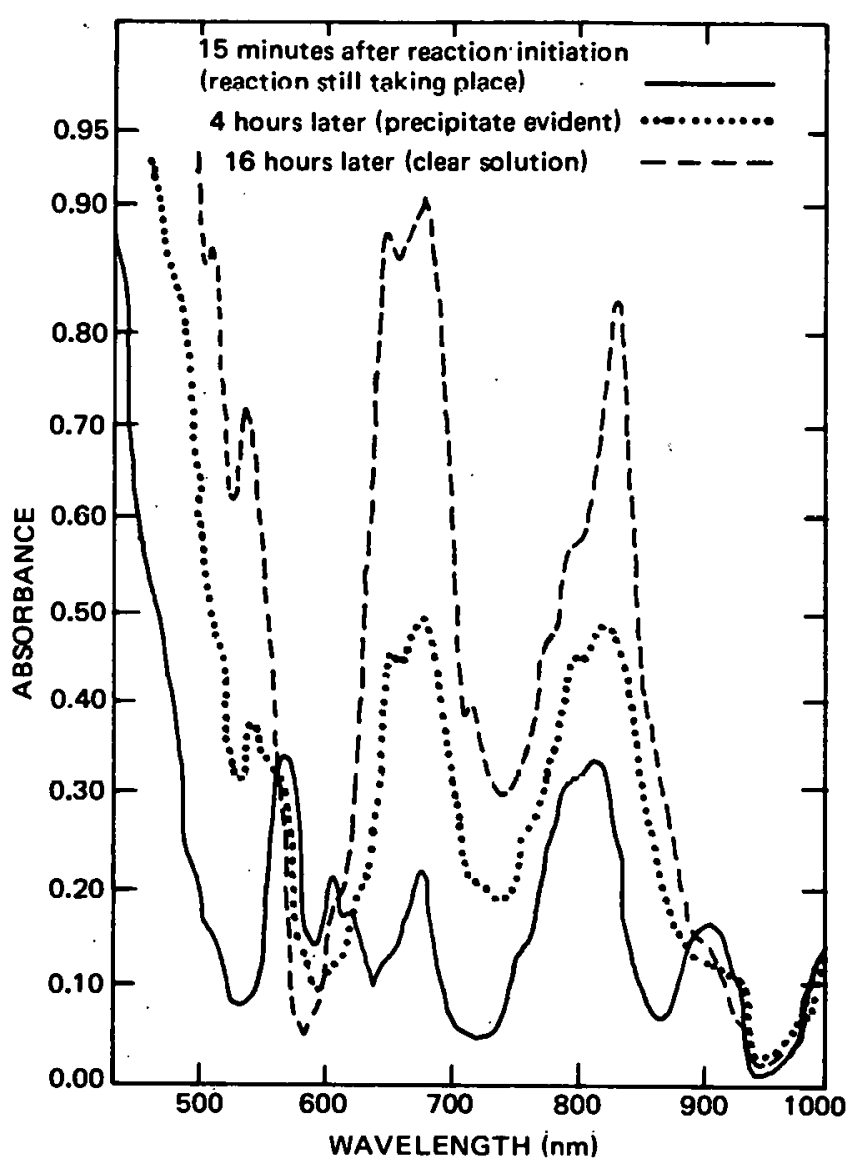

FIGURE 12. Electronic Spectra of $\mathrm{CCl}_{a} / \mathrm{CH}_{7} \mathrm{OH} / \mathrm{Pu}^{\circ}$ Reaction Mixture at Various Reaction Intervals.

(2) methyl orange

(3) thymol blue

(4) methyl yellow

\section{Results of Experiment 6}

Table 3 shows the approximate $\mathrm{pH}$ ranges exhibited by fresh and aged $\mathrm{CCl}_{4} / \mathrm{CH}_{3} \mathrm{OH}$ mixtures. With the exception of thymol blue, a neutral color developed (as determined in neat anhyitrous $\mathrm{CH}_{3} \mathrm{OH}$ ) for freshly mixed solutions on addition of the indicator powders. The thymol blue solution rapidly changed color from neutral $\mathrm{pH}$ range (yellow) to acid $\mathrm{pH}$ range (red). The aged mixtures exhibited acid $\mathrm{pH}$ range colors with all 
TABLE 2. Plutonium Precipitates.

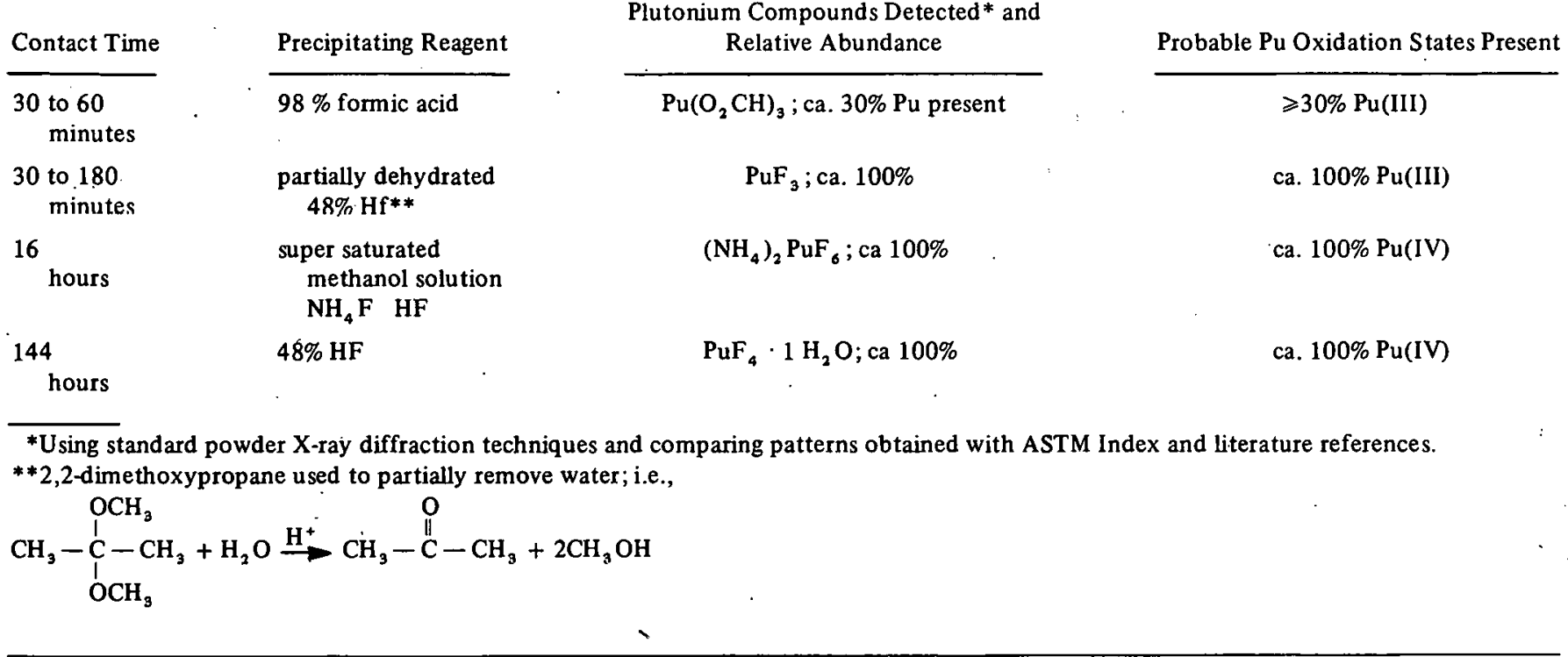

TABLE 3. Colored Indicator $\mathrm{pH}$ Determination of Fresh and Aged $\mathrm{CCl}_{4} / \mathrm{CH}_{3} \mathrm{OH}$ Mixtures.

\begin{tabular}{|c|c|c|c|c|}
\hline Indicator & $\begin{array}{l}\text { Expected } \mathrm{pH} \text { range } \\
\text { color }\end{array}$ & $\begin{array}{c}\mathrm{CH}_{3} \mathrm{OH} \text {. Solution } \\
\text { color }\end{array}$ & $\begin{array}{c}\text { Fresh } \mathrm{CCl}_{4} / \mathrm{CH}_{3} \mathrm{OH} \\
\text { color }\end{array}$ & $\begin{array}{c}\text { Aged } \mathrm{CCl}_{4} / \mathrm{CH}_{3} \mathrm{OH} \\
\text { color }\end{array}$ \\
\hline$\rho$-naphtholbenzein & $\begin{array}{c}0.0-0.8 ; 8.2-10.0 \\
\text { green } \leftrightarrow \text { brown } \leftrightarrow \text { orange } \\
\text { green }\end{array}$ & brown & orange-brown & brown \\
\hline methyl orange & $\begin{array}{l}3.2-4.4 ; 4.4< \\
\text { red } \leftrightarrow \text { yellow }\end{array}$ & yellow & yellow & red \\
\hline thymol blue & $\begin{array}{l}1.2-2.8 ; 8.0-9.6 \\
\text { red } \leftrightarrow \text { yellow } \leftrightarrow \text { blue }\end{array}$ & yellow & $\begin{array}{l}\text { changed from } \\
\text { yellow to red } \\
\text { within minutes }\end{array}$ & red violet \\
\hline methyl yellow & $\begin{array}{l}2.9-4.0 ; 4.0< \\
\text { red } \leftrightarrow \text { yellow }\end{array}$ & ycllow & yellow & red \\
\hline
\end{tabular}

of the indicators used. The apparent, rapid acidification reaction encountered with thymol blue is not understood. Further investigation of this unexpected reaction will be pursued.

\section{Survey of $\mathrm{CCl}_{4} / \mathrm{CH}_{3} \mathrm{OH} / \mathrm{Metal}$ Reactivity}

Qualitative experiments were performed to survey the reactivity of $\mathrm{CCl}_{4} / \mathrm{CH}_{3} \mathrm{OH} /$ metal mix tures. The reactions were accomplished at ambient conditions in 1-inch by 3 -inch glass vials.
Qualitative assessment of reactivity was accomplished by visual observation and apparent heat generation.

\section{Experiment 7}

$\mathrm{CCl}_{4} / \mathrm{CH}_{3} \mathrm{OH} / \mathrm{metal}^{\circ}$ (purity $>99 \%$ )
(1) cerium (chips)
(2) samarium (chips)
(3) magnesium (chips) 
RFP-2181

TABLE 4. Qualitative Comparison of $\mathrm{CCl}_{4} / \mathrm{CH}_{3} \mathrm{OH} / \mathrm{Metal}$ Reactivity with Electropositivity of Metals.

\begin{tabular}{ll} 
Metal & $\begin{array}{l}\text { Visual Description of } \\
\text { Reaction Product Mixture }\end{array}$ \\
\hline Cerium & $\begin{array}{l}\text { Yellow colored solution } \\
\text { that changes color to } \\
\text { red on storage. }\end{array}$ \\
Mamarium & $\begin{array}{l}\text { Colorless solution con- } \\
\text { taining a white precipitate }\end{array}$ \\
Plutonium & $\begin{array}{l}\text { Colorless solution con- } \\
\text { taining a white precipitate }\end{array}$ \\
& $\begin{array}{l}\text { Blue-green colored solution } \\
\text { that changes color to } \\
\text { brown on storage. A black } \\
\text { precipitate was evident but } \\
\text { dissolved on storage. }\end{array}$
\end{tabular}

Thorium

Beryllium

Uranium

Hafuluin .

Aluminum

Titanium

Zirconium

Manganese

Zinc

Iron

Nickel

Copper
Colorless solution containing a white precipitate

Colorless solution containing a large amount of white precipitate

Red-purple colored solution that rapidly changes to green. $\Lambda$ black precipitate was formed and dissolved on storagc.

ivo reacitun

Colorless solution containing a white precipitate

No reartinn .

No reaction

Red-brown colored solution that changes to brown

Colorless solution containing a white precipitate

Yellow colored solution containing a light yellow precipitate

Light green colored solution containing a green precipitate

Light green colored solution containing a green precipitate
Qualitative Description of Mixture Reactivity

Vigorous exothermic reaction that initiates immediately on $\mathrm{Ce}^{\circ}$-solution contact

Vigorous exothermic reaction that initiates immediately on $\mathrm{Sm}^{\circ}$-solution contact

Vigorous exothermic reaction that initiates immediately on $\mathrm{Mg}^{\circ}$-solution contact

Vigorous exothermic reaction that initiates $30 \mathrm{sec}$ to $1 \mathrm{~min}$ after $\mathrm{Pu}^{\circ}$-solution contact

Slow reaction that initiates $\sim 1$ hour after $\mathrm{Th}^{\circ}$-solution contact

Vigorous exothermic reaction that initiates $\sim 1 \mathrm{~min}$ after $\mathrm{Be}^{\circ}$ solution contact

Vigorous exothermic reaction that initiates 1 to $5 \mathrm{~min}$ after $\mathrm{U}^{\circ}$-solution contact

Nó reaaction after 2 month $\mathrm{Hf}^{\circ}$-solution contact

Vigorous exothermic reaction that initiates immediately after $\mathrm{Al} \hat{l}^{\wedge}$-solitión cóntact

No reastion aftor 3 montho $\mathrm{Ti}^{\circ}$-solution contact

No reaction after 2 months $\mathrm{Zr}^{\circ}$-solution contact

Slow reaction that initiates several days after $\mathrm{Mn}^{\circ}$ solution contact

Modcratcly vigorous exothermic reaction that initiates 1 to $5 \mathrm{~min}$ after $\mathrm{Zn}^{\circ}$-solution contact

Slow reartinn that initiates several days aftor $\mathrm{Fo}^{\circ}$-solution contact

Slow reaction that initiates 1 to 2 weeks after $\mathrm{Ni}^{\circ}$-solution contact

Slow reaction that initiates 1 to 2 months after $\mathrm{Cu}^{\circ}$. solution contact
Oxidation-Reduction Couples in Acid Solution ${ }^{5}$

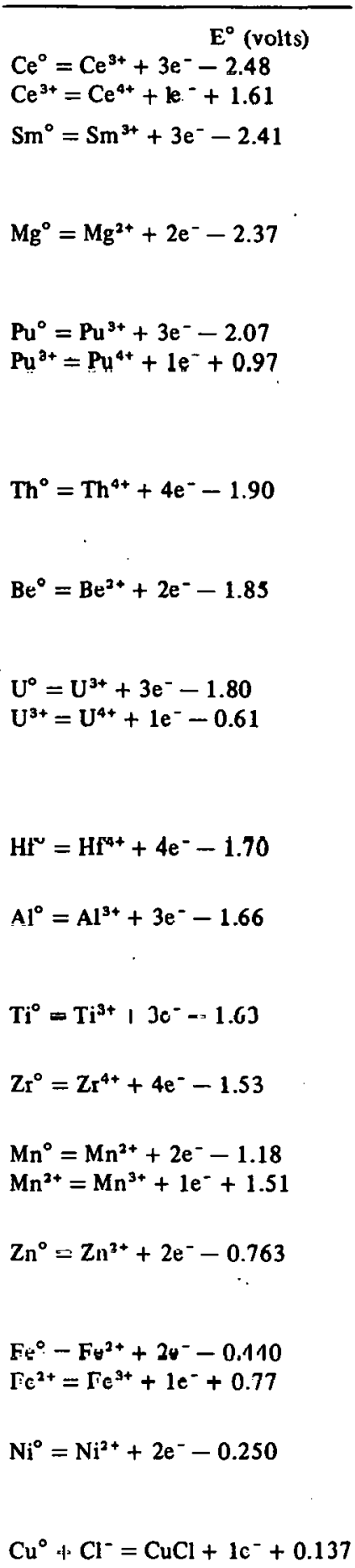


(4) plutonium (chips and coupons)

(5) thorium (chips)

(6) beryllium (chips and coupons)

(7) uranium (chips and coupons)

(8) hafnium (crystals)

(9) aluminum (foil and wire)

(10) titanium (crystals)

(11) zirconium (coupons)

(12) manganese (powder)

(13) zinc (chips)

(14) iron (powder)

(15) nickel (coupons and powder)

(16) copper (chips)

\section{Results of Experiment 7}

Table 4 shows the relative reactivity of a number of metals with $\mathrm{CCl}_{4} / \mathrm{CH}_{3} \mathrm{OH}$. A general qualitative parallel in reactivity and metal electropositivity was apparent from the observations listed. Hafnium, titanium, and zirconium metals werc exceptions to this trend. These metals appeared nonreactive with $\mathrm{CCl}_{4} / \mathrm{CH}_{3} \mathrm{OH}$ at the ambient conditions cited.

\section{Identification of Products Formed in $\mathrm{CCl}_{4} / \mathrm{CH}_{3} \mathrm{OH} / \mathrm{Metal}$ Reactions (Other Than $\mathrm{Pu}^{\circ}$ )}

Liquid products of $\mathrm{CCl}_{4} / \mathrm{CH}_{3} \mathrm{OH} /$ metal reactions were investigated by direct probe mass spectral analysis using a C.E.C. 110 mass spectrometer. Metals ranging from highly reactive to only slightly reactive were used to obtain a survey of reaction products. The metal specimens were weighed, then reacted with $1.5-\mathrm{mI} \mathrm{CCl}_{4} / \mathrm{CH}_{3} \mathrm{OH}$ in 1 -inch by 3 -inch stoppered glass vials. Cyclohex ane
$\left(\mathrm{C}_{6} \mathrm{H}_{12}\right)$ was used as an internal reference. The C.E.C. 110 instrument parameters were accelerating voltage- $70 \mathrm{eV}$ and $10^{-6} \mathrm{~mm} \mathrm{Hg}$; sample temperature varied from $\sim 55$ to $200^{\circ} \mathrm{C}$.

\section{Experiment 8}

Internal reference $0.6 \%$ by volume $\mathrm{C}_{6} \mathrm{H}_{12}$

(1) $0.1401 \mathrm{~g}$ cerium

(2) $0.0024 \mathrm{~g}$ magnesium

(3) $0.2380 \mathrm{~g}$ uranium

(4) $0.0270 \mathrm{~g}$ aluminum

(5) $0.0549 \mathrm{~g}$ manganese

\section{Results of Experiment 8}

Table 5 shows some of the volatile components formed in $\mathrm{CCl}_{4} / \mathrm{CH}_{3} \mathrm{OH} /$ metal reaction mix tures. and their relative abundance. Chloroform was the major volatile product formed. Relative to chloroform, small quantities of hexachloroethane, 1,1-dimethoxymethane (methanal), dichloromethane, and monochloromethane were detected. In all reaction mix tures investigated, chloroform was in greater abundance (several orders of magnitude) than any other volatile product detected.

\section{Stimulation of $\mathrm{CCl}_{4} / \mathrm{CH}_{3} \mathrm{OH} / \mathrm{Metal}$ Reactions}

Stimulation potential was cursorily investigated, for one type of organic compound in $\mathrm{CCl}_{4} / \mathrm{CH}_{3} \mathrm{OH} /$ metal reaction systems. Reaction-initiation stimulation was attempted with several of the previously found, slowly reactive $\mathrm{CCl}_{4} / \mathrm{CH}_{3} \mathrm{OH} /$ metal systems, in addition to $\mathrm{CCl}_{4} / \mathrm{CH}_{3} \mathrm{OH} / \mathrm{Pu}^{\circ}$. Experiments were conducted in 1 -inch by 3 -inch stoppered glass vials. Plutonium reactions were accomplished in the inert system described previously. All other tests were conducted at ambient conditions in an air atmosphere. All metals investigated formed colored species. Visual observation of gas evolution and colored 
TABLE 5. Abundance of Volatile Components in $\mathrm{CCl}_{4} / \mathrm{CH}_{3} \mathrm{OH} /$

Metal Reaction Mixtures ( 0.081 mmole $\mathrm{C}_{6} \mathrm{H}_{12}$ internal standard).

\begin{tabular}{|c|c|c|c|c|c|c|c|}
\hline $\begin{array}{l}\text { Metal Reacted } \\
\text { (1.0 mmole) }\end{array}$ & $\begin{array}{l}\mathrm{CHCl}_{3} \\
\text { (mmole) }\end{array}$ & $\begin{array}{c}\mathrm{C}_{2} \mathrm{Cl}_{6} \\
\text { (mmole) }\end{array}$ & $\begin{array}{c}\mathrm{CH}_{2}\left(\mathrm{OCH}_{3}\right)_{2} \\
\text { (mmole) }\end{array}$ & $\begin{array}{l}\mathrm{CH}_{2} \mathrm{Cl}_{2} \\
\text { (detected) }\end{array}$ & $\begin{array}{c}\mathrm{CH}_{3} \mathrm{Cl} \\
\text { (detected) }\end{array}$ & $\begin{array}{c}\mathrm{CCl}_{4} \text { Remaining } \\
\text { After Reaction } \\
\text { (mmoles) }\end{array}$ & $\begin{array}{c}\mathrm{CCl}_{4} \text { Reacted } \\
\text { (mmoles) }\end{array}$ \\
\hline Cerium & 1.5 & $<0.002$ & 0.008 & * & $*$ & 6.9 & 4.3 \\
\hline Magnesium & 0.9 & 0.016 & $<0.004$ & * & * & 8.9 & 2.3 \\
\hline Uranium & 2.4 & 0.008 & 0.005 & * & * & 8.2 & 3.0 \\
\hline Manganese** & 0.2 & $<0.002$ & $<0.004$ & - & - & 11.1 & 0.1 \\
\hline
\end{tabular}

*These components were detected but in such low amounts they were not quantitated.

**This slow reaction had just started at sampling time but was included because $\mathrm{CHCl}_{3}$ was detected even at this early stage.

species formation were compared with non"additive" reaction systems for an estimation of reaction stimulation. Several stimulated reaction product mixtures were investigated by the direct probe, C.E.C. 110 mass spectroscopy technique described previously to ascertain if a stimulantmetal reaction product was formed.

\section{Experiment 9}

Stimulation additive 2,4-pentanedione* was added prior to metal-solution contact
(1) cerlum $+\mathrm{CCl}_{4} / \mathrm{CH}_{3} \mathrm{OH} / 10 \mathrm{vol} \% \mathrm{HAcAc}$
(2) uranium $+\mathrm{CCl}_{4} / \mathrm{CH}_{3} \mathrm{OH} / 10$ vol $\% \mathrm{HAcAc}$
(3) Plutonium $+\mathrm{CCl}_{4} / \mathrm{CH}_{3} \mathrm{OH} / 10$ vol $\% \mathrm{HAcAc}$
(4) manganese $+\mathrm{CCl}_{4} / \mathrm{CH}_{3} \mathrm{OH} / 10 \mathrm{vol} \% \mathrm{HAcAc}$
(5) iron $+\mathrm{CCl}_{4} / \mathrm{CH}_{3} \mathrm{OH} / 10$ vol \% $\mathrm{HAcAc}$

\section{Results of Experiment 9}

Table 6 shows the observations of the efforts to stimulate reaction initiation in $\mathrm{CCl}_{4} / \mathrm{CH}_{3} \mathrm{OH} /$ metal systems. Addition of 2,4-pentanedione (a $\beta$-diketone) to $\mathrm{CCl}_{4} / \mathrm{CH}_{3} \mathrm{OH} /$ metal reaction systems significantly

\footnotetext{
$* 2,4$-pentanedione $=$ acetylacctone $=$ HAcAc.
}

reduces reaction induction periods. The short induction periods noted for the reactive metals $\mathrm{Ce}^{\circ}, \mathrm{U}^{\circ}$, and $\mathrm{Pu}^{\circ}$ were reduced to near zero. The expected formation of metal acetylacetonate compounds was confirmed by mass spectral analysis of isolated, solid residues from several of these reaction mix tures.

\section{Corrosion Tests of Potential Containment Metals for $\mathrm{CCl}_{4} / \mathrm{CH}_{3} \mathrm{OH}$}

The corrosion of a number of potential containment materials for liquid $\mathrm{C}^{\prime} \mathrm{Cl}_{4} / \mathrm{CH}_{3} \mathrm{OH}$ was investigated by weight-loss techniques. Metal specimens were degreased by a $\mathrm{CCl}_{4}$ rinse and allowed to air-dry. The test 3 werc conducted in 1 -inch by 3 -inch stoppered glass vials at ambient conditions (air atmosphere). Specimens were weighted, surface area determined, and stored submerged in a $\mathrm{CCl}_{4} / \mathrm{CH}_{3} \mathrm{OH}$ solution. Periodically, the specimens were removed from the reaction media, rinsed with a small portion of fresh $\mathrm{CCl}_{4} / \mathrm{CII}_{3} \mathrm{OH}$, and reweighed. The specimens were then returned to the reartinn system. Fxperiments were terminated when rapid attack was notcd.

During the investigation of large-scale $\mathrm{CCl}_{4} / \mathrm{CH}_{3} \mathrm{OH} /$ $\mathrm{Pu}^{\circ}$ reactions, gross metal corrosion became apparent on the interior surfaces of the inert glovebox. The box was constructed from $304 \mathrm{~L}$ stainless steel. An additional corrosion study was 
TABLE 6. Stimulation of $\mathrm{CCl}_{4} / \mathrm{CH}_{3} \mathrm{OH} / \mathrm{Metal}$ Reactions.

\begin{tabular}{|c|c|c|}
\hline & Reactant Metals* & $\begin{array}{l}\text { Visual Description of Stimulated } \\
\mathrm{CCl}_{4} / \mathrm{CH}_{3} \mathrm{OH} / \mathrm{Metal} \text { Reactions }\end{array}$ \\
\hline & Cerium** & $\begin{array}{l}\text { Immediate exothermic reaction } \\
\text { on } \mathrm{Ce}^{\circ} \text {-solution contact }\end{array}$ \\
\hline & Uranium ** & Same as above \\
\hline & Plutonium** & Same as above \\
\hline & Manganese & $\begin{array}{l}\text { Approximately } 30 \text {-minute } \\
\text { initiation period. Slow reaction. }\end{array}$ \\
\hline$\ddots$ & Iron & $\begin{array}{l}\text { Approximatcly } 1 \text {-hour initiation } \\
\text { period. Slow reaction. }\end{array}$ \\
\hline
\end{tabular}
Comparison of Stimulated and Nonstimulated $\mathrm{CCl}_{4} / \mathrm{CH}_{3} \mathrm{OH} / \mathrm{Metal}$ Reactivity

\footnotetext{
*Stimulant for each metal was HAcAc products:

Cerium $=\mathrm{Ce}(\mathrm{AcAc})_{4}$

Uranium $=U(A c A c)_{4} ; U(A c A c)_{3} \mathrm{Cl} ; \mathrm{U}(\mathrm{AcAc})_{2} \mathrm{Cl}_{2}$

Plutonium $=\mathrm{Pu}(\mathrm{AcAc})_{4} ; \mathrm{Pu}(\mathrm{AcAc})_{3} \mathrm{Cl}$
}

**Mass spectral investigation of the volatile metal reaction products of these stimulated reactions found the following

undertaken by $\mathrm{Briggs}^{49}$ to determine vapor-phase attack of $\mathrm{CCl}_{4} / \mathrm{CH}_{3} \mathrm{OH}$ on potential construction metals for process equipment such as gloveboxes, storage tanks, and reaction containers. The metals tested were subjected to refluxing $\mathrm{CCl}_{4} / \mathrm{CH}_{3} \mathrm{OH}$ vapor (in an air atmosphere); corrosion rates are summarized in Appendix IV.

\section{Experiment 10}

The following metals were investigated for liquid-phase $\mathrm{CCl}_{4} / \mathrm{CH}_{3} \mathrm{OH}$ corrosion:

(1) Galvanized iron

(2) Type 347 stainless steel

(3) Type 304 stainless steel

(4) Type 316 stainless steel

(5) Monel-Type 400

(6) Fluorinator reactor-grade nickel
Results of Experiment 10

Figure 13 compares $\mathrm{CCl}_{4} / \mathrm{CH}_{3} \mathrm{OH}$ corrosion rates of a number of metals and metal alloys. Nickel was the most resistant to attack. Once attack initiated, a catastrophic degradation occurred for all of the metals investigated.

\section{Plutonium Stripping from $\mathrm{CCl}_{4} / \mathrm{CH}_{3} \mathrm{OH} / \mathrm{Pu}^{n}$ Reaction Mixtures}

The results obtained in Experiment $5 \mathrm{~b}$ indicate that a number of plutonium precipitating reagents have potential for removing plutonium species in $\mathrm{CCl}_{4} / \mathrm{CH}_{3} \mathrm{OH} / \mathrm{Pu}^{\circ}$ reaction mix tures. The stripping method selected for this investigation was used only to complement normal Rocky Flats metalproduction process streams.

The $\mathrm{CCl}_{4} / \mathrm{CH}_{3} \mathrm{OH} / \mathrm{Pu}^{\circ}$ reaction mixtures from a number of large-scale reactions were accumulated until 2 to 3 litre batches at $\sim 100 \mathrm{~g} / 1 \mathrm{Pu}^{\circ}$ were collected. This period ranged from 1 to 16 days. The plutonium was present as $\mathrm{Pu}(\mathrm{IV}$ ) species. 


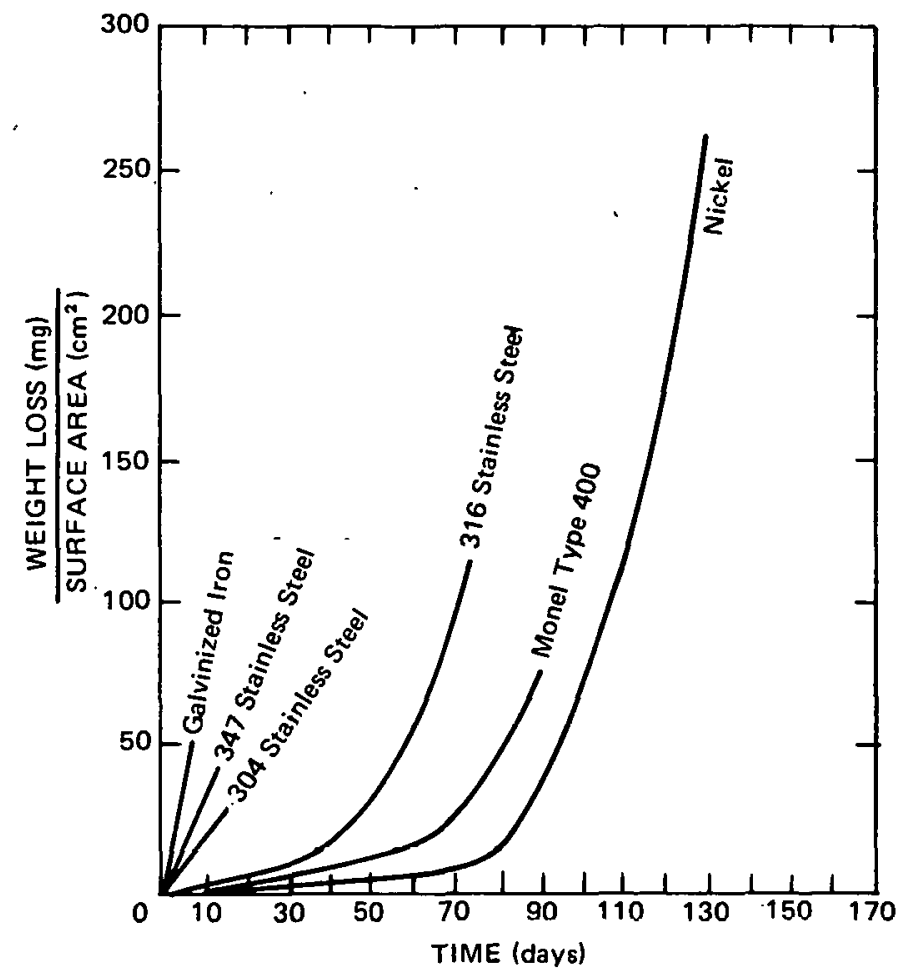

FIGURE 13. Corrosion of Potential Containment Metals by $\mathrm{CCl}_{4} / \mathrm{CH}_{3} \mathrm{OH}$.

The $\mathrm{Pu}(\mathrm{IV})$ species were reduced to $\mathrm{Pu}(\mathrm{III})$ species by adding a slight excess of dry ascorbic acid, with rapid stirring. The reduction [i.e., $\mathrm{Pu}(\mathrm{IV}) \rightarrow \mathrm{Pu}(\mathrm{III})]$ reaction appeared to occur rapidly at ambient temperatures ( 30 to 60 minutes was allowed to ensure complete reduction).

A slight excess of dry oxalic acid was added to the reaction mixture containing the reduced $\mathrm{Pu}(\mathrm{III})$ species. Plutonium(III) oxalate formed and was isolated by vacuum filtration. The filtrate was generally decontaminated to $10^{-4} \mathrm{~g} / 1$ plutonium in one pass of this operation. Solvent vapors were removed from the Pu(III) oxalate by vacuum at ambient temperature. The $\mathrm{Pu}$ (III) oxalate was then calcined in air at $\sim 500^{\circ} \mathrm{C}$. The $\mathrm{PuO}_{2}$ formed by this operation was compatible with the currently used hydrofluorination, metal-reduction techniques employed at Rocky Flats for plutonium metal production.

\section{DISCUSSION}

A rapid weight loss was noted for plutonium metal in contact with $\mathrm{CCl}_{4} / \mathrm{CH}_{3} \mathrm{OII}^{3}$ In addition, this investigation has demonstrated that many metals are attacked by the liquid and vapor phases of this mixture at ambient conditions. A brief visual observation of a $\mathrm{CCl}_{4} / \mathrm{CH}_{3} \mathrm{OH} / \mathrm{Pu}^{\circ}$ solution reaction was as follows:

Phase 1 - An apparent reaction induction period ( $\sim 30$ seconds to 1 minute) was followed by bubbles forming at pinpoint sites on the metal surface. The metal surface at the attack sites changed appearance from metallic to black. The solution became blue in the immediate area of the attack sites.

Phase 2 - The reaction was exothermic and appeared to boil. The reaction sites enlarged and eventually covered the entire metal surface with a black coating. The reaction solution was blue to blue-green.

Phase 3 - After the turbulent reaction subsided, the reaction solution was clear and blue-green. Following several hours in storage, the solution darkened to a final color of brown.

The following discussion concen a number of reaction parameters pertinent toward employment of this reaction system in a nonaqueous plutoniumprocessing effort.

\section{Reaction Rates}

Weight-loss rates of $\sim 21\left(\mathrm{mg} / \mathrm{cm}^{2}\right) / \mathrm{min}$ were found for the temperature rise portion of reaction systems with ratio $\leqslant 5$. Constant temperature reaction rates were $\sim 13\left(\mathrm{mg} / \mathrm{cm}^{2}\right) / \mathrm{min}$. In reaction systems where complete plutonium dissolution did not occur during the exothermic reaction phase (e.g., Experiment 3 , ratio $\sim 1.8$ ), a significant metal weight loss $[\sim 5(\mathrm{~g} / 1) /$ day $]$ continued after several weeks of storage.

Reaction initiation in $\mathrm{CCl}_{4} / \mathrm{CH}_{3} \mathrm{OH} / \mathrm{Pu}^{\circ}$ systems at subambient temperatures $\left(-26{ }^{\circ} \mathrm{C}\right)$ was slow (5 to 10 minutes). As one would predict, the 
reaction rate at a subambient temperature was reduced when compared with the ambient temperature value $\sim 13\left(\mathrm{mg} / \mathrm{cm}^{2}\right) / \mathrm{min}$. The off-gas rates indicated $\sim 1$ mole gas was produced per $\sim 7$ moles $\mathrm{Pu}^{\circ}$ consumed. The boiling appearance of this reaction was brought about by the exothermic nature of the reaction causing the major organic product, $\mathrm{CHCl}_{3}$, and unreacted solvent, $\mathrm{CCl}_{4} /$ $\mathrm{CH}_{3} \mathrm{OH}$, to boil. The major gas detected was hydrogen. Chloroform $\left(\mathrm{CHCl}_{3}\right)$ vapor was also detected in the off-gas products of $\mathrm{CCl}_{4} / \mathrm{CH}_{3} \mathrm{OH} /$ metal reactions.

\section{Reaction Products}

The reaction product mix ture from $\mathrm{CCl}_{4} / \mathrm{CH}_{3} \mathrm{OH} /$ $\mathrm{Pu}^{\circ}$ was complex, and some products appeared easily altered. Qualitative detection of the following compounds was achieved during this and previous investigations (see Appendix I): $\mathrm{PuCl}_{3}, \mathrm{CHCl}_{3}$, $\mathrm{H}_{2}$, and trace amounts of $\mathrm{PuH}_{2}, \mathrm{CH}_{2} \mathrm{Cl}_{2}, \mathrm{CH}_{3} \mathrm{Cl}$, $\mathrm{C}_{2} \mathrm{Cl}_{6}$, and $\mathrm{CH}_{2} \mathrm{O}$. All attempts to identify either or both alkoxides and chloralkoxides of plutonium [i.e., $\mathrm{Pu}\left(\mathrm{OCH}_{3}\right)_{\mathrm{X}} \mathrm{Cl}_{3-\mathrm{x}}$ and $\mathrm{Pu}\left(\mathrm{OCH}_{3}\right)_{\mathrm{X}} \mathrm{Cl}_{4-\mathrm{X}}$ ] failed. Several $\mathrm{Pu}(\mathrm{IV})$ alkoxides have been previously reported. ${ }^{50}$ Plutonium(III) alkoxides and $\mathrm{Pu}$ (III) and (IV) mixed chloroalkoxides have not been reported.

Electronic spectral data and precipitation experiments indicate plutonium metal was oxidized to a $\mathrm{Pu}$ (III) species during the initial exothermic reaction of this mixture. The reaction was rapid and probably paralleled the weight-loss rates previously discussed. The Pu(III) species were oxidized to Pu(IV) species in what seems to be a second, slower reaction. Solid precipitates were experienced during almost all phases of reaction at various times throughout this investigation.

On storage for $\sim 16$ hours, nearly all solids present were solubilized. Solutions containing $\sim 100 \mathrm{~g} / \mathrm{l}$ of the Pu(IV) species were stored for several months in the inert box system with no evidence of post precipitation.* The $\mathrm{Pu}(\mathrm{IV})$ species formed in the $\mathrm{CCl}_{4} / \mathrm{CH}_{3} \mathrm{OH} / \mathrm{Pu}^{\circ}$ reaction mixture on storage

\footnotetext{
*In an earlier investigation of this reaction system, Pitts found plutonium concentrations as high as $482 \mathrm{~g} / \mathrm{l}$ but indicated that above $230 \mathrm{~g} / \mathrm{l}$, solid materials were always present (Appendix I).
}

could be quantitatively reduced, in situ, to Pu(III) species (ambient conditions) by ascorbic acid.

\section{Reaction Stimulation}

One approach to reaction stimulation would be the addition of heat energy (either by an external source such as a heater, or an internal source such as a primary exothermic reaction). Since this reaction is sufficiently exothermic to achieve solution reflux temperatures, once initiated at ambient temperatures, this mode of stimulation was not pursued. A second approach, which was investigated, was stimulation by product solubilization. The addition of $\beta$-diketone compounds (example: 2,4-pentanedione) could be expected to produce organic solvent, soluble plutonium complexes with all of the plutonium compounds found or predicted for the $\mathrm{CCl}_{4} / \mathrm{CH}_{3} \mathrm{OH} / \mathrm{Pu}^{\circ}$ reaction mixture; i.e.,

$$
\begin{aligned}
\mathrm{PuCl}_{3}+\mathrm{HAcAc} \rightarrow \mathrm{Pu}(\mathrm{AcAc})_{4} & \\
& +\mathrm{Pu}(\mathrm{AcAc})_{\mathrm{X}} \mathrm{Cl}_{4-\mathrm{x}}+--- \\
\mathrm{PuH}_{2}+\mathrm{HAcAc} \rightarrow \mathrm{Pu}(\mathrm{AcAc})_{4}+\mathrm{H}_{2}+--- & \\
\mathrm{Pu}\left(\mathrm{OCH}_{3}\right)_{3}+\mathrm{HAcAc} \rightarrow \mathrm{Pu}(\mathrm{AcAc})_{4} & +\mathrm{Pu}(\mathrm{AcAc})_{\mathrm{X}}\left(\mathrm{OCH}_{3}\right)_{4-\mathrm{x}}+---
\end{aligned}
$$

The addition of 2,4-pentanedione to the $\mathrm{CCl}_{4} / \mathrm{CH}_{3} \mathrm{OH} /$ metal reaction systems significantly reduced the observed reaction induction period as compared to nonstimulated systems.

\section{Postulated Reaction Mechanism}

Data obtained from these investigations and the literature reviewed indicate that several reactions have the potential for, and probably are simultaneously occurring in $\mathrm{CCl}_{4} / \mathrm{CH}_{3} \mathrm{OH} / \mathrm{Pu}^{\circ}$ reaction systems. This attempt to propose an overall reaction sequence must be considered only as a first approximation of the actual heterogeneous reaction system. Following are five reaction sequences and the anticipated degree of participation in $\mathrm{CCl}_{4} / \mathrm{CH}_{3} \mathrm{OH} /$ metal reaction. 
Substitution Reaction

A slow substitution reaction would be expected for $\mathrm{CCl}_{4} / \mathrm{CH}_{3} \mathrm{OH}$ mixtures. Samples stored for 6 months yielded acid $\mathrm{pH}$ range values (Table 3 ).

$$
\begin{aligned}
\mathrm{Cl}_{3}-\mathrm{C}-\mathrm{Cl}+\mathrm{CH}_{3} \mathrm{OH} & \stackrel{\text { slow }}{\longrightarrow} \\
\left(\mathrm{Cl}_{3} \mathrm{C}-\mathrm{OH}\right) \stackrel{\text { fast }}{\longrightarrow} & \left(\mathrm{Cl}_{3}-\mathrm{C}-\mathrm{OH}\right)+\mathrm{CH}_{3} \mathrm{Cl} \\
\text { (phosgene) } & \mathrm{Cl}_{2} \mathrm{CO}+\mathrm{HCl}
\end{aligned}
$$

Side reactions

$$
\mathrm{Cl}_{2} \mathrm{CO}+2 \mathrm{CH}_{3} \mathrm{OH} \rightarrow \mathrm{CH}_{3} \mathrm{O}
$$$$
-\stackrel{\mathrm{O}}{\mathrm{C}}-\mathrm{UCH}_{3}+2 \mathrm{HCl} \rightarrow---
$$

(dimethylcarbonate)

$$
\mathrm{CH}_{3} \mathrm{OH}+\mathrm{HCl} \rightleftharpoons \mathrm{CH}_{3} \mathrm{Cl}+\mathrm{H}_{2} \mathrm{O}
$$

\section{Autoprotolysis-Redox.Reactions}

Aqueous electromotive force (emf) values, $, 5,11$ combined with the indicated increased reactivity paralleling electropositivity (i.e., $\mathrm{Ce}>\mathrm{Mg}>\mathrm{Pu}>$ $\mathrm{U}>\mathrm{Mn}>\mathrm{Fe}$ ), suggest a second, feasible, reaction sequence.

Autoprotolysis of methanol

$$
2 \mathrm{CH}_{3} \mathrm{OH} \rightleftharpoons \mathrm{CH}_{3} \mathrm{OH}_{2}{ }^{\prime}+\mathrm{CH}_{3} \mathrm{O}
$$

Two Rcdox Reactions:

Redox No. $1^{5}$

$\mathrm{Pu}^{\circ} \rightarrow \mathrm{Pu}^{3+}+3 \mathrm{e}^{-}$

\section{Organometallic Intermediates}

This reaction sequence was not considered as plausible as the previously described redox reactions; however, the reaction path was considered for the following reasons:

(1) The major products would be the same type as expected from the redox reactions.

(2) Detailed investigations of the $\mathrm{CCl}_{4} / \mathrm{CH}_{3} \mathrm{OH} / \mathrm{Zn}^{\circ}$ reaction system ${ }^{32}$ could be used to predict this sequence.

(3) Plutonium metal would be more reactive than zinc metal and should have the potential to form organometallic compounds.

Initial Reaction

$\mathrm{Pu}^{\circ}+\mathrm{CCl}_{4} \rightarrow\left(\mathrm{Cl}_{3} \mathrm{CPuCl}\right)$

Fast Transient Secondary Reactions

$\left(\mathrm{Cl}_{3} \mathrm{CPuCl}\right)+\mathrm{CCl}_{4} \rightarrow\left(\mathrm{Cl}_{3} \mathrm{C}\right)_{2} \mathrm{PuCl}_{2}$

$\left(\mathrm{Cl}_{3} \mathrm{C}\right)_{2} \mathrm{PuCl}_{2}+2 \mathrm{CH}_{3} \mathrm{OH} \rightarrow\left(\mathrm{CH}_{3} \mathrm{O}\right)_{2} \mathrm{PuCl}_{2}$

$+2 \mathrm{CHCl}_{3}$

$\left(\mathrm{Cl}_{3} \mathrm{CPuCl}\right)+\mathrm{CII}_{3} \mathrm{OII} \rightarrow\left[\left(\mathrm{CII}_{3} \mathrm{O}\right) \mathrm{PuCl}\right]+\mathrm{CIICl}_{3}$

$\left[\left(\mathrm{CH}_{3} \mathrm{O}\right) \mathrm{PuCl}\right]+\mathrm{CH}_{3} \mathrm{OH} \rightarrow\left(\mathrm{CH}_{3} \mathrm{O}\right)_{2} \mathrm{PuCl}+1 / 2 \mathrm{H}_{2}$

$3 \mathrm{CH}_{3} \mathrm{OH}_{2}^{+}+3 \mathrm{CH}_{3} \mathrm{O}^{-}+3 \mathrm{e}^{-} \rightarrow 3 / 2 \mathrm{H}_{2}+3 \mathrm{CH}_{3} \mathrm{O}^{-}+3 \mathrm{CH}_{3} \mathrm{OH}$

overall reaction $3 \mathrm{CH}_{3} \mathrm{OH}+\mathrm{Pu}^{\circ} \rightarrow \mathrm{Pu}\left(\mathrm{CH}_{3} \mathrm{O}\right)_{3}+3 / 2 \mathrm{H}_{2}$

Redox No. $2^{5,40}$

$E^{\circ}$

$\mathrm{Pu}^{\circ} \rightarrow \mathrm{Pu}^{3+}+3 \mathrm{e}^{-}$

-2.07 volts*

$\mathrm{CCl}_{4}+\mathrm{CH}_{3} \mathrm{OH}_{2}^{+}+\mathrm{CH}_{3} \mathrm{O}^{-}+2 \mathrm{e}^{-} \rightarrow \mathrm{CHCl}_{3}+\mathrm{Cl}^{-}+\mathrm{CH}_{3} \mathrm{O}^{-}+\mathrm{CH}_{3} \mathrm{OH}$

-0.504 volts

overall reaction $2 \mathrm{Pu}^{\circ}+3 \mathrm{CCl}_{4}+3 \mathrm{CH}_{3} \mathrm{OH} \rightarrow \mathrm{Pu}\left(\mathrm{OCH}_{3}\right)_{3}+\mathrm{PuCl}_{3}+3 \mathrm{CHCl}_{3}$

-1.57 volts

\footnotetext{
*No attempt was made to correct for the expected deviations encountered when using aqueous and nonaqueous emf values. Although this value can only be viewed as a first approximation, the magnitude is large and one would predict a spontaneous reaction for the reaction as written.
} 
Overall Reaction

$$
\begin{aligned}
2 \mathrm{Pu}^{\circ}+\mathrm{CCl}_{4}+5 \mathrm{CH}_{3} \mathrm{OH} \rightarrow\left(\mathrm{CH}_{3} \mathrm{O}\right)_{2} \mathrm{PuCl}_{2} \\
+\left(\mathrm{CH}_{3} \mathrm{O}\right)_{3} \mathrm{PuCl}+3 \mathrm{CHCl}_{3}+\mathrm{H}_{2}
\end{aligned}
$$

Side Reactions

$$
\begin{aligned}
& \mathrm{CCl}_{4} \rightarrow \cdot \mathrm{CCl}_{3}+\cdot \mathrm{Cl} \\
& 2 \cdot \mathrm{CCl}_{3} \rightarrow \mathrm{C}_{2} \mathrm{Cl}_{6} \\
& \cdot \mathrm{CCl}_{3}+\mathrm{CH}_{3} \mathrm{OH} \rightarrow \mathrm{H}_{2} \mathrm{CO}+\mathrm{CHCl}_{3}
\end{aligned}
$$

Plutonium Metal Hydrogen Gas Reaction

Pitts ${ }^{3}$ detected plutonium hydride on the surface of plutonium metal attacked by $\mathrm{CCl}_{4} / \mathrm{CH}_{3} \mathrm{OH}$. The exothermic hydriding reaction would contribute to the heat generated from the $\mathrm{CCl}_{4} / \mathrm{CH}_{3} \mathrm{OH} / \mathrm{Pu}^{\circ}$ reaction.

$$
\mathrm{Pu}^{\circ}+\mathrm{H}_{2}(\mathrm{~g}) \rightarrow \mathrm{PuH}_{2} \text { (solid) }{\Delta \mathrm{H}^{\circ}}_{\mathrm{f}_{298}}=-45.6 \frac{\mathrm{kcal}}{\mathrm{mole}}^{(42 \mathrm{~b})}
$$

Secondary Reaction

$$
4 \mathrm{PuH}_{2}+5 \mathrm{CCl}_{4} \rightarrow 4 \mathrm{PuCl}_{3}+8 \mathrm{HCl}+5 \mathrm{C}
$$

Plutonium(III) to Plutonium(IV) Oxidation Reaction

Plutonium(III) species were predicted for the majority of reaction sequences described.

Experimentation showed that Pu(III) species were formed initially, but these species were subsequently oxidized (rather slowly) to Pu(IV) species. The following path was suggested to explain this apparent secondary oxidation reaction.

Step 1 - Assume $\mathrm{PuCl}_{3}$ is a major product from $\mathrm{CCl}_{4} / \mathrm{CH}_{3} \mathrm{OH} / \mathrm{Pu}^{\circ}$ reaction. An alcoholysis reaction would then occur* with the formation of hydrogen chloride; viz,

\footnotetext{
*Pitts probably observed this reaction when he found that $\mathrm{PuCl}_{3}$-methanol solution dissolved plutonium metal (A ppendix I).
}

$$
\mathrm{PuCl}_{3}+\mathrm{XCH}_{3} \mathrm{OH} \rightleftharpoons \mathrm{Pu}\left(\mathrm{OCH}_{3}\right)_{\mathrm{X}} \mathrm{Cl}_{3-\mathrm{x}}+\mathrm{XHCl}
$$

Step 2 - Low oxidation state alkoxide or chloroalkoxide compounds of elements having multiple oxidation states are unstable toward oxidation by reaction with an alcohol, ${ }^{28} \mathrm{viz}$,

$$
\begin{aligned}
\mathrm{Pu}(\mathrm{III})\left(\mathrm{OCH}_{3}\right)_{\mathrm{X}} \mathrm{Cl}_{3-\mathrm{X}}+1 \mathrm{CH}_{3} \mathrm{OH} \rightarrow & \\
& \mathrm{Pu}(\mathrm{IV})\left(\mathrm{OCH}_{3}\right)_{\mathrm{X}+1} \mathrm{Cl}_{3-\mathrm{x}}+1 / 2 \mathrm{H}_{2}
\end{aligned}
$$

Summation of the Proposed Reaction Sequences

A number of logical reaction sequences would be predictable in the $\mathrm{CCl}_{4} / \mathrm{CH}_{3} \mathrm{OH} / \mathrm{Pu}^{\circ}$ reaction system. The predominate sequence would involve the two autoprotolysis-redox reactions described earlier. The driving force for Redox No. 1 would be greatly reduced by the predictable low solubility of $\mathrm{Pu}\left(\mathrm{OCH}_{3}\right)_{3}$ in $\mathrm{CCl}_{4} / \mathrm{CH}_{3} \mathrm{OH}$. Redox No. 2 would produce $\mathrm{PuCl}_{3}$, which would be soluble in $\mathrm{CCl}_{4} / \mathrm{CH}_{3} \mathrm{OH}$, thus allowing the reaction to proceed. To a lesser extent than the redox reactions, the substitution, hydriding, and finally the alcoholysis-oxidation reactions and noted side reactions would be expected to add to the overall reactivity and complexity demonstrated by $\mathrm{CCl}_{4} / \mathrm{CH}_{3} \mathrm{OH} / \mathrm{Pu}^{\circ}$.

The apparent synergistic nature of the $\mathrm{CCl}_{4} /$ $\mathrm{CH}_{3} \mathrm{OH} / \mathrm{Pu}^{\circ}$ reaction can be explained in the following manner. A potentially strong oxidizing agent $\left(\mathrm{CCl}_{4}\right)$ undergoes reaction with a strong reducing agent $\left(\mathrm{Pu}^{\circ}\right)$ in a solvent $\left(\mathrm{CH}_{3} \mathrm{OH}\right)$ that meets the following criteria:

(1) Complete miscibility with the oxidant $\mathrm{CCl}_{4}$.

(2) Undergoes autoprotolysis.

(3) Would have high solubility for "Lewis acid" products formed from the reductant $\mathrm{Pu}^{\circ}$ [ such products as $\mathrm{PuCl}_{3}$ and $\mathrm{Pu}\left(\mathrm{OCH}_{3}\right)_{\mathrm{X}}$ $\left.\mathrm{Cl}_{3-\mathrm{x}}\right]$.

Using these assumptions, the reduced reactivity of an apparently similar reaction system $\left(\mathrm{CHCl}_{3} /\right.$ $\left.\mathrm{CH}_{3} \mathrm{OH} / \mathrm{Pu}^{\circ}\right)^{3}$ can be explained as follows: 
RFP-2181

Redox of Chloroform ${ }^{40}$

$E^{?}$

$\mathrm{Pu}^{\circ} \rightarrow \mathrm{Pu}^{3+}+3 \mathrm{e}^{-}$

-2.07 volts

$\mathrm{CHCl}_{3}+\mathrm{CH}_{3} \mathrm{OH}_{2}^{+}+2 \mathrm{e}^{-} \rightarrow \mathrm{CH}_{2} \mathrm{Cl}_{2}+\mathrm{Cl}^{-}+\mathrm{CH}_{3} \mathrm{OH}$

-1.45 volts

overall reaction $2 \mathrm{Pu}^{\circ}+3 \mathrm{CHCl}_{3}+3 \mathrm{CH}_{3} \mathrm{OH} \rightarrow \mathrm{Pu}\left(\mathrm{OCH}_{3}\right)_{3}+\mathrm{PuCl}_{3}+3 \mathrm{CH}_{2} \mathrm{Cl}_{2}$

-0.62 volts

The difference of -0.95 volts [i.e., $(-1.57)$ $-(-0.62)=-0.95]$ would account for the reduced reactivity noted for $\mathrm{CHCl}_{3} / \mathrm{CH}_{3} \mathrm{OH} / \mathrm{Pu}^{\circ}$ compared to $\mathrm{CCl}_{4} / \mathrm{CH}_{3} \mathrm{OH} / \mathrm{Pu}^{\circ}$.

\section{Corrosion of Containment Materials}

No suitable construction metal was found in this investigation for long-term storage of liquid $\mathrm{CCl}_{4} / \mathrm{CH}_{3} \mathrm{OH}$. The vapor corrosion investigation by Briggs ${ }^{49}$ (see Appendix IV) indicated that Hastelloy $C \circledast$, Hastelloy $F \circledast$, Hastelloy $X \otimes$, and Inconel 625 exhibited excellent corrosion resistance to $\mathrm{CCl}_{4} / \mathrm{CH}_{3} \mathrm{OH}$ vapors. These alloys will be investigated for liquid corrosion resistance.

\section{Future Investigations}

Organic reaction mixture-Pu ${ }^{\circ}$ systems investigations are continuing. The following objectives are of interest:

1. Pressure developed in a constant volume system owing to the off-gas products and exothermic nature of the $\mathrm{CCl}_{4} / \mathrm{CH}_{3} \mathrm{OH} / \mathrm{Pu}^{\circ}$ reaction.

2. Corrosion-resistant construction material to contain liquid $\mathrm{CCl}_{4} / \mathrm{CH}_{3} \mathrm{OH} / \mathrm{Pu}^{\circ}$ reaction systems and process solutions.

3. Confirmation of proposed $\mathrm{CCl}_{4} / \mathrm{CH}_{3} \mathrm{OH} /$ metal reaction mechanism.

4. Additional qualitative and quantitative data for $\mathrm{CCl}_{4} / \mathrm{CH}_{3} \mathrm{OH} / \mathrm{Pu}^{\circ}$ reaction products.

5. Investigation of other reaction systems; i.e., $\mathrm{CCl}_{3} \mathrm{Br} / \mathrm{CH}_{3} \mathrm{OH} / \mathrm{Pu}^{\circ}$ and $\mathrm{CCl}_{3} \mathrm{C} \equiv \mathrm{N} / \mathrm{CH}_{3} \mathrm{OH} / \mathrm{Pu}^{\circ}$ (Appendix V).

\section{REFERENCES}

1. S. H. Pitts, Jr. RFP-566. The Dow Chemical Company, Rocky Flats Division. (1965).

2. S. H. Pitts, Jr. RFP-688. The Dow Chemical Company, Rocky Flats Division. (1266).

3. (a) S. H. Pitts, Jr., unpublished results (see Appendix I); (b) S. H. Pitts, Jr., U. S. Patent No. 3,718,677. (1973).

4. Serious Accident Serics No. 246. U.S. Atomic Energy Commission, Washington, D.C. (1965).

5. Handbook of Chemistry and Physics. 44th Ed. Published by The Chemical Rubber Publishing Co., Cleveland, Ohio.

b. G. Scátçhar̃d, S. E. Wood, and J. M. Mochel. J. Am. Chern. Soc. 68:1960-3 (1946).

7. International Critical Table. Vol. III. pp 237 and 245. McGraw-Hill Book Co., Inc., New York and Iondon (1928).

8. W. J. Jones, S. T. Bowder, W. W. Yarnold, and W. H. Jones. J. Phys. and Colloid Chem. 52:753-60 (1948).

9. H. Sadak and R. M. Fuoss. J. Am. Chem. Soc. 76:5897-901 (1954).

10. I. Gyenes. Titration in Non-Aqueous Media. p 21 and references therein. Iliffe Book, Ltd,, London, and D. VanNostrancl Co. Inc., Princeton, New Jersey (1967).

11. W. L. Latimer. The Oxidation States of the Elements and Their Potentials in Aqueous Solutions. 2nd Ed., p 142. Prentice-Hall, Inc., Englewood Cliffs, New Jersey, (1952). 
12. J. D. Minford, M. H. Brown, and R. H. Brown. $J$. Electrochem. Soc. 106:185-99 and references therein (1959).

13. Yu. G. Kryanzhev, V. B. Petrinski, and L. M. Romanova. Izv. A kad. Nauk. SSR, Ser, Khim. 7:1606-8 (1969).

14. B. C. Roguitte and M. H. J. Wijneu. J. Am. Chem. Soc. 85:2053 (1963).

15. H. Lux, D. Sarre, and J. Schaffelhofer. Chem. Ber. 97: 2301-5 (1964).

16. T. Kiba and K. Terrada. J. Chem. Soc. (Japan), Pure Chem Sert. 75:196-8 (1954).

17. M. Asscher and D. Vafsi. J. Chem. Soc. (London). p 947-52 (1968).

18. C. Y. Meyers, A. M. Malte, and W. S. Matthews. J. Am. Chem. Soc. 91:7510-12 (1969).

19. R. Dubrisay and G. Arditti. Compt rend 204:1568-70 (1937).

20. A. Michael and A. Murphy, Jr. Am. Chem. J. 44:365-84 (1910).

21. R. H. Atkinson, J. Steigman, and C. F. Hiskey. Anal. Chem. 24:477-88 (1952).

22. H. A. Wilhelm and R. M. Bergman. Iowa State 1900, M-10 through M-12 (1967).

23. J. Hine and M. Hine. J. Am. Chem. Soc. 74:5266-77 and references therein (1952).

24. L. F. Fieser and M. Fieser. Advanced Organic Chemistry. p 285. Reinhold Publishing Corp., New York, New York (1965).

25. J. R. Leith, J. W. Hightower, and C. G. Harkins. Corrosion 26 (9): 3.77-80 (1970).

26. J. D. Roberts and M. C. Caserio. Basic Principles of Organic Chemistry. pp 391-2. W. A. Benjamin, Inc., New York, New York (1965).

27. Ibid, pp 400-4.
28. D. C. Bradley. Progress in Inorganic Chemistry. Vol. II, p 306. Interscience Publishers, Inc., New York, New York (1960).

29. A. R. Eberle and M. W. Lerner. Metallurgia 59:49-52 and references therein (1959).

30. A. E. Baker and H. M. Haendler. Inorg. Chem. $1: 127-30$ (1962).

31. E. Rabald. Werkstoffe U. Korrosion 12:695-8 (1961).

32. S. J. Gromov and G. A. Katazev. Tr. Tomsk. Gos. Univ. Vol. 154:128-31 (1962).

33. H. Lund. Chem. Ber. 67B:935-8 (1934).

34. G. A. Kataev. Chem. Abstr. 52. 16846d (1958).

35. C. Boller. Fette. Seifen. Anstrichmittel 56 (12):978-81 (1954).

36. S. W. Vorster. Corr. Sci. 9:801-811 (1969).

37. R. L. Horst, Jr., E. H. Hollingsworth, and W. King. Corrosion 25:198-207 (1969).

38. G. A. Razavayev and N. S. Vasileiskaya. Doklady A kad. Nauk. S.S.S.R. 80:69-72 (1951).

39. G. A. Razuvaev and Yu. A. Sorokin. J. Gen. Chem. (USSR) 23 (9):1589-92 (1953).

40. J. M. Kolthoff, T. S. Lee, D. Stocesova and E. P. Parry. Anal. Chem. 22:521-5 (1950).

41. J. M. Cleveland. The Chemistry of Plutonium. Gordon and Breach Science Publishers, New York, New York (1970).

42. (a) F. L. Oetting, Chem, Rev. 67:267 (1967); (b) F. L. Oetting and D. R. Horrell. RFP-2170 Rocky Flats Division, Dow Chemical U.S.A. (1974).

43. D. B. Patterson, J. G. Miller, and W. W. Lucasse. J. Chem. Educ. 20:319-26 (1942). 
44. J. G. Miller, A. I. Lowell, and W. W. Lucasse. J. Chem. Educ. 24:121-3 (1947).

45. A Laboratory Manual of General Chemistry. 5th Ed. pp 187-91. Wm. C. Brown Co., Dubuque, Iowa. (1966).

46. C. H. Shomate and E. F. Huffman. J. Am. Chem. Soc. 65:1625 (1943).

47. D. Cohen. J. Inorg. Nucl. Chem. 18:211-18 (1961).

48. (a) L. R. Crisler, U.S. Patent 3,660,047 (1972);

(b) L. R. Crisler, J. Inorg. Nucl. Chem., $35: 4309$ (1973).
49. J. L. Briggs. Rocky Flats Division, Dow Chemical U.S.A., unpublished results.

50. D. C. Bradley, B. Harder, and F. Hudswell. J. Chem. Soc. (London). p 3318 (1957).

51. H. Gilman. Organic Chemistry, Advanced Treatise. Vol. II, p 1853. John Wiley and Sons, Inc., New York, New York (1943).

52. G. W. A. Fowles, D. A. Rice, N. Rolfe, and R. A. Walton, Chem Comm. pp459-60 (1970). 


\section{APPENDIX I}

Selected Data from Unpublished Investigations by S. H. Pitts

1. Mixtures of 40 to $60 \mathrm{vol} \% \mathrm{CCl}_{4}$ react most rapidly in $\mathrm{CCl}_{4} / \mathrm{CH}_{3} \mathrm{OH} / \mathrm{Pu}^{\circ}$ system at ambient initiation conditions as shown in Figure 14.

2. A number of halocarbon-alcohol mixtures were reactive with plutonium metal. Examples presented were:

$$
\mathrm{CCl}_{4} / \mathrm{CH}_{3}-\mathrm{CH}_{2}-\mathrm{OH}
$$<smiles>CC(C)(O)C(Cl)Cl</smiles>

$\mathrm{CCl}_{4} / \mathrm{CH}_{3}-\left(\mathrm{CH}_{2}\right)_{2}-\mathrm{CH}_{2}-\mathrm{OH}$

$\mathrm{CHCl}_{3} / \mathrm{CH}_{3} \mathrm{OH}$

$\mathrm{CCl}_{3}-\mathrm{CH}_{3} / \mathrm{CH}_{3} \mathrm{OH}$

$\mathrm{CFCl}_{2}-\mathrm{CClF}_{2} / \mathrm{CH}_{3} \mathrm{OH}$

FIGURE 14. Plutonium Metal Reaction with $\mathrm{CCl}_{4} / \mathrm{CH}_{3} \mathrm{OH}$ Solutions.

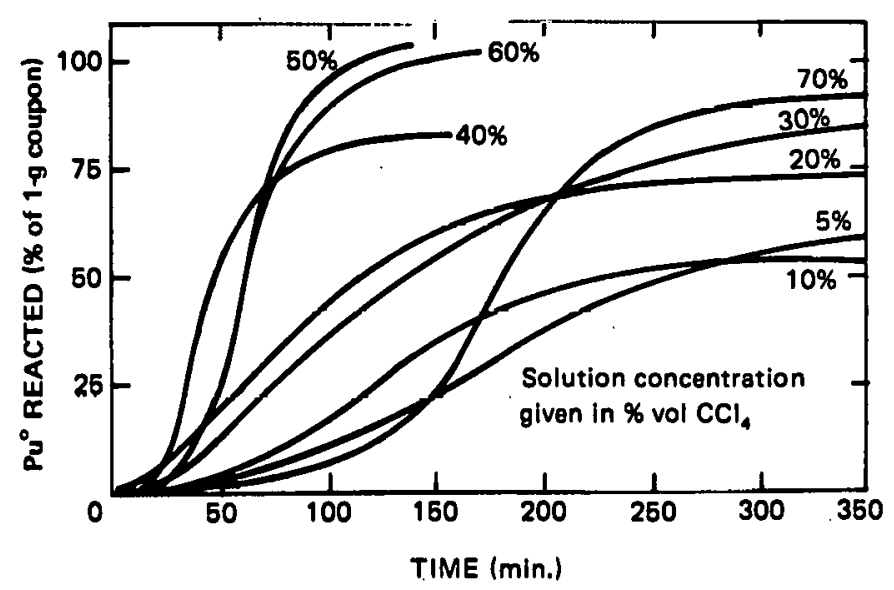

All mix tures investigated were less reactive with plutonium metal at ambient conditions (slower reaction) than $50: 50 \mathrm{vol} \% \mathrm{CCl}_{4} / \mathrm{CH}_{3} \mathrm{OH}$.

3. The following reaction products were identified in $\mathrm{CCl}_{4} / \mathrm{CH}_{3} \mathrm{OH} / \mathrm{Pu}^{\circ}$ reaction mixtures:

$$
\begin{aligned}
& \mathrm{PuCl}_{3} \\
& \mathrm{CHCl}_{3} \\
& \mathrm{H}_{2} \uparrow \\
& \mathrm{PuH}_{2} \\
& \mathrm{CH}_{2} \mathrm{Cl}_{2} \\
& \mathrm{CH}_{3} \mathrm{Cl} \\
& \mathrm{C}_{2} \mathrm{Cl}_{6} \\
& \mathrm{CH}_{2} \mathrm{O}
\end{aligned}
$$

4. Plutonium concentrations as high as $482 \mathrm{~g} / \mathrm{l}$ were found for $\mathrm{CCl}_{4} / \mathrm{CH}_{3} \mathrm{OH} / \mathrm{Pu}^{\circ}$ reaction mixtures. Solid materials were evident at concentrations $>230 \mathrm{~g} / 1$.

5. The mixture, $\mathrm{PuCl}_{3} / \mathrm{CH}_{3} \mathrm{OH}$, reacted with (dissolved) plutonium metal.

6. The mixture, $\mathrm{HgCl}_{2} / \mathrm{CH}_{3} \mathrm{OH}$, reacted with (dissolved) plutonium metal.

7. The mixture, $\mathrm{NaCl} / \mathrm{CH}_{3} \mathrm{OH}$, reacted with (corroded) plutonium metal. 


\section{APPENDIX II}

\section{Physical Constants (Properties) of $\mathrm{CCl}_{4}, \mathrm{CH}_{3} \mathrm{OH}$, and $\mathrm{CCl}_{4} / \mathrm{CH}_{3} \mathrm{OH}$}

Molecular Weight:

$$
\begin{array}{lr}
\mathrm{CH}_{3} \mathrm{OH} & 32.04 \mathrm{~g} / \mathrm{mole} \\
\mathrm{CCl}_{4} & 153.84 \mathrm{~g} / \mathrm{mole}
\end{array}
$$

Conversion Factors:

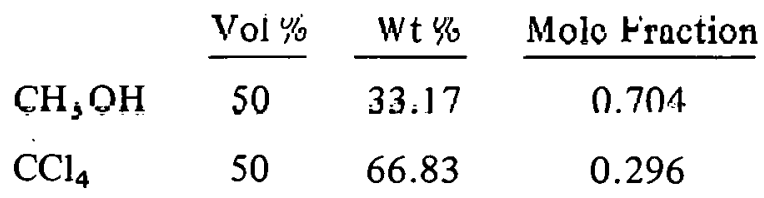

Vapor Pressure: ${ }^{5-7}$

Boiling point of $\mathrm{CH}_{3} \mathrm{OH}$ at $760 \mathrm{~mm} \mathrm{Hg}$ is $64.65^{\circ} \mathrm{C}$

\begin{tabular}{|c|c|c|}
\hline${ }^{\circ} \mathrm{C}$ & $\mathrm{mm} \mathrm{Hg}$ & $\mathrm{lb} / \mathrm{in}^{2}$ \\
\hline 25 & 240 & 4.64 \\
\hline .35 & 315 & 6.09 \\
\hline 55 & 750 & 14.50 \\
\hline 100 & 2,280 & 44.10 \\
\hline 140 & 6,612 & 127.88 \\
\hline 180 & 15,960 & 308.67 \\
\hline 220 & 33,440 & 646.73 \\
\hline 240 & 17,120 & 911.30 \\
\hline
\end{tabular}

Boiling point of $\mathrm{CCl}_{4}$ at $760 \mathrm{~mm} \mathrm{Hg}$ is $76.8^{\circ} \mathrm{C}$

1:1 Volume Mixture:

Density: ${ }^{5,6}$

$$
\mathrm{CCl}_{4} \text { at } 20^{\circ} \mathrm{C} \quad 1.595 \mathrm{~g} / \mathrm{ml}
$$

$1: 1$ volume mix ture at $25^{\circ} \mathrm{C} \quad 1.194 \mathrm{~g} / \mathrm{ml}$

Viscosity: ${ }^{5,8}$

Centipoises

$\mathrm{CH}_{3} \mathrm{OH}$ at $-44.5^{\circ} \mathrm{C}$

$-22.3$

1.22

0.0

0.82

15.0

0.62

20.0

0.60

40.0

0.46

$\mathrm{CCl}_{4}$ at $\quad 0.0^{\circ} \mathrm{C}$

1.33

15.0

1.04

20.0

0.97

40.0

0.74

$1: 1$ volume mixture at $25.0^{\circ} \mathrm{C}$

0.77

Diẹlectric Constant: 5,9

$\mathrm{CH}_{3} \mathrm{OH}$ at $25^{\circ} \mathrm{C}$

$\frac{\epsilon}{326}$

$\mathrm{CCl}_{4}$ at $20^{\circ} \mathrm{C}$

$1: 1$ volume mixture at $25^{\circ} \mathrm{C}$

16.8

Specific Heat: ${ }^{5} \mathrm{CH}_{3} \mathrm{OH}$ at $\quad 0.0{ }^{\circ} \mathrm{C} \quad 0.566 \mathrm{cal} / \mathrm{g} /{ }^{\circ} \mathrm{C}$ $\mathrm{CCl}_{4}$ at $\quad 0.0^{\circ} \mathrm{C} \quad 0.198 \mathrm{ial} / \mathrm{g} /{ }^{\circ} \mathrm{C}$ $20.0^{\circ} \mathrm{C} \quad 0.201 \mathrm{cal} / \mathrm{g} /{ }^{\circ} \mathrm{C}$

Thermodynamic Functions: ${ }^{6}$

$1: 1$ volume mixture at $35^{\circ} \mathrm{C}\left(308.16^{\circ} \mathrm{K}\right)$ Excess change free energy on mixing $-\mathrm{G} F-258 \mathrm{cal} / \mathrm{mole}$

Heat of mixing $-\mathrm{H}^{\mathrm{M}}=+77 \mathrm{cal} / \mathrm{mole}$ Excess change entropy on mixing $\left(308.16^{\circ} \mathrm{K}\right)$ $\mathrm{S}_{\mathrm{X}}^{\mathrm{E}}=-181 \mathrm{cal} / \mathrm{mole}$

Flash Puint: ${ }^{5} \mathrm{CH}_{3} \mathrm{OH} \sim 52^{\circ} \mathrm{F}$

$\mathrm{CCl}_{4}$ none

$1: 1$ volumc mixture $-26^{\circ} \mathrm{C}\left(7.8 .8^{\circ} \mathrm{F}\right)^{*}$

Autuprotulysis (methanol): ${ }^{10}$

$$
\begin{aligned}
& 2 \mathrm{CH}_{3} \mathrm{OH} \rightleftharpoons \mathrm{CH}_{3} \mathrm{OH}_{2}^{+}+\mathrm{CH}_{3} \mathrm{O}^{-} \\
& \text {pK } \text { auto }=16.7
\end{aligned}
$$

\footnotetext{
*Determined at this laboratory by Cleveland open-cup method.
} 


\section{APPENDIX III}

\section{Reagents and Metals Used for This Investigation}

Carbon tetrachloride, "Baker Analyzer" reagent grade. A constant lot number was used throughout this investigation. $>10 \mathrm{ppm}$ water.

Methanol (anhydrous), Merck reagent grade. A constant lot number was used throughout this investigation. Approximately $100 \mathrm{ppm}$ water.
Plutonium metal, gallium-stabilized $\Delta$-phase .

Plutonium metal, electrorefined, $<200 \mathrm{ppm}$ total metallic impurities, was used to determine heat of reaction $\mathrm{CCl}_{4} / \mathrm{CH}_{3} \mathrm{OH} / \mathrm{Pu}^{\circ}$.

Reagents Used for Qualitative Investigations:

Formic acid, 90.97\%, "Baker Analyzed" reagent grade

Hydrofluoric acid, 48\% B\&A reagent grade

Ammonium bifluoride, Baker purified grade

2,4-pentanedione, Eastman white label

Bromotrichloromethane, Eastman yellow label

Trichloroacetonitrile, Eastman white label

Iron powder, "Baker Analyzed" reagent grade

Manganese powdcr, "Bakcr Analyzed" reagent grade

Zinc chips, "Baker Analyzed" reagent grade

Nickel powder, Fisher reagent grade (low cobalt)

Cerium chips, 99.9\% Research Inorganic Chemicals

Samarium chips, 99+\% Research Inorganic Chemicals

Thorium chips, 99.5\% Research Inorganic Chemicals

Zirconium coupon, 99.5\% Research Inorganic Chemicals

Hafnium crystals, $99.97 \%$ Research Inorganic Chemicals

Titanium crystals, 99.95\% Research Inorganic Chemicals

Magnesium turnings, Mallinckrodt Analytical reagent grade

Aluminum wire, Mallinckrodt Analy tical reagent grade

Copper chips, Mallinckrodt Analy tical reagent grade 


\section{APPENDIX IV}

Unpublished Results for Vapor Phase Corrosion of Metals by Briggs. ${ }^{49}$

\begin{tabular}{|c|c|c|}
\hline \multicolumn{3}{|c|}{$\mathrm{CCl}_{4} / \mathrm{CH}_{3} \mathrm{OH}$ Vapor Phase Corrosion of Metals } \\
\hline Test Sample Type & $\begin{array}{l}\text { Exposure Time } \\
\text { (hours) }\end{array}$ & $\begin{array}{l}\text { Corrosion Rate } \\
\text { (mpy)* }\end{array}$ \\
\hline 304 stainless steel & 7 & $\begin{array}{l}560.00 \\
490.00\end{array}$ \\
\hline 304L stainless steel & 7 & $\begin{array}{l}270.00 \\
280.00\end{array}$ \\
\hline 316 stainless steel & 7 & $\begin{array}{l}40.00 \\
40.00\end{array}$ \\
\hline 321 stainless steel & 7 & $\begin{array}{l}320.00 \\
270.00\end{array}$ \\
\hline 347 stainless steel & 7 & $\begin{array}{l}110.00 \\
180.00\end{array}$ \\
\hline Ti-0.2 Pd (alloy) & 4 & $\begin{array}{l}740.00 \\
950.00\end{array}$ \\
\hline Incolloy 800 & 56 & $\begin{array}{l}40.00 \\
20.00\end{array}$ \\
\hline Monel 400 & 630 & $\begin{array}{l}1.60 \\
2.20\end{array}$ \\
\hline Inconel 625 & 630 & $\begin{array}{l}0.20 \\
0.20\end{array}$ \\
\hline Hastelloy X® & 630 & $\begin{array}{l}0.30 \\
0.30\end{array}$ \\
\hline Hastelloy $F \otimes$ & 630 & $\begin{array}{l}0.60 \\
U . \%\end{array}$ \\
\hline Hastelloy $\mathrm{C} \circledast$ & 630 & $\begin{array}{l}0.05 \\
0.06\end{array}$ \\
\hline Carpenter $20 \mathrm{Cb}-3$ & 630 & $\begin{array}{l}2.00 \\
2.00\end{array}$ \\
\hline Haynes 25 & 630 & $\begin{array}{l}2.00 \\
3.00\end{array}$ \\
\hline
\end{tabular}

Summary: Hastclloy C, Hastelloy F, Hastelloy X and Inconel-625 exhibited low corrosion rates and could probably be used for process boxes and equipment in contact with $\mathrm{CCl}_{4} / \mathrm{CH}_{3} \mathrm{OH}$ vapors.

$\overline{* m p y}=$ mils penetration per year. 


\section{APPENDIX $\mathrm{V}$}

\section{Preliminary Results for Two Other Organic Reaction Systems with Plutonium Metal.}

Pitts reported that several halocarbon-alcohol mixtures* attacked $\mathrm{Pu}^{\circ}$ at reduced rates when compared to $\mathrm{CCl}_{4} / \mathrm{CH}_{3} \mathrm{OH}$, and that methanol was the most reactive alcohol tested. ${ }^{3}$ This result seems plausible when the reaction sequences previously described are considered. The potential substitution of $\mathrm{CCl}_{4}$ by a more reactive halocarbon is of continued interest. Two other halocarbon liquid compounds $\left(\mathrm{CCl}_{3} \mathrm{Br}\right.$ and $\left.\mathrm{CCl}_{3}-\mathrm{C} \equiv \mathrm{N}\right)$ were tested for reactivity with $\mathrm{Pu}^{\circ}$ in methanol. A brief description of each halocarbon's properties compared with $\mathrm{CCl}_{4}$ follows:

\section{Bromotrichloromethane $\left(\mathrm{CCl}_{3} \mathrm{Br}\right)$}

1. More polar than $\mathrm{CCl}_{4}$.

2. $\mathrm{C}-\mathrm{Cl}$ bond strength $66.5 \mathrm{kcal} / \mathrm{mole}^{51}$ $\mathrm{C}-\mathrm{Br}$ bond strength $54.0 \mathrm{kcal} / \mathrm{mole}^{.51}$

3. Higher boiling point than $\mathrm{CCl}_{4} \cdot\left(104^{\circ} \mathrm{C}\right.$ compared to $78^{\circ} \mathrm{C}$.)

4. Higher melting point than $\mathrm{CCl}_{4} \cdot\left(-6{ }^{\circ} \mathrm{C}\right.$ compared to $-23^{\circ} \mathrm{C}$.)

Trichloroace tonitrile $\left(\mathrm{CCl}_{3}-\mathrm{C} \equiv \mathrm{N}\right)$

1. More polar than $\mathrm{CCl}_{4}$.

2. Capable of acting as a "Lewis basc" (i.c., could form $\mathrm{PuCl}_{3} \cdot \mathrm{CCl}_{3} \mathrm{C} \equiv \mathrm{N}$ complexes).

3. Wider liquid range than $\mathrm{CCl}_{4}$ (melting point $-44{ }^{\circ} \mathrm{C}$; boiling point $85^{\circ} \mathrm{C}$ at $741-\mathrm{mm} \mathrm{Hg}$ compared to $-23^{\circ} \mathrm{C}$ and $77^{\circ} \mathrm{C}$ respectively for $\mathrm{CCl}_{4}$ ).

4. Can act as an oxidizing agent. ${ }^{52}$

$$
\begin{aligned}
& \mathrm{WCl}_{5}+\mathrm{CCl}_{3} \mathrm{C}=\mathrm{N} \rightarrow \mathrm{WCl}_{6} \cdot 2 \mathrm{CCl}_{3} \mathrm{C}=\mathrm{N}+--- \\
& \mathrm{Mo}(\mathrm{IV})+\mathrm{CCl}_{3} \mathrm{C} \equiv \mathrm{N} \rightarrow \mathrm{Mo}(\mathrm{V})+--- \\
& \mathrm{Nb}(\mathrm{IV})+\mathrm{CCl}_{3} \mathrm{C} \equiv \mathrm{N} \rightarrow \mathrm{Nb}(\mathrm{V})+--- \\
& \mathrm{Ti}(\mathrm{III})+\mathrm{CCl}_{3} \mathrm{C} \equiv \mathrm{N} \rightarrow \mathrm{Ti}(\mathrm{IV})+---
\end{aligned}
$$

The plutonium-metal, weight-loss rates of the reaction systems $\mathrm{CCl}_{3} \mathrm{Br} / \mathrm{CH}_{3} \mathrm{OH} / \mathrm{Pu}^{\circ}$ and $\mathrm{CCl}_{3}-\mathrm{C} \equiv \mathrm{N} / \mathrm{CH}_{3} \mathrm{OH} / \mathrm{Pu}^{\circ}$ were investigated. The experiments were performed in the same manner described for the small-scale $\mathrm{CCl}_{4} / \mathrm{CH}_{3} \mathrm{OH} / \mathrm{Pu}^{\circ}$ reaction rate investigations $(\leqslant 10-\mathrm{ml}$ solution).

\section{Experiment}

a. $5.0 \mathrm{ml} \mathrm{CCl} \mathrm{Cl}_{3} \mathrm{Br} / 5.0 \mathrm{ml} \mathrm{CH} \mathrm{CH}_{3} \mathrm{OH}$, surface area $5 \mathrm{~cm}^{2}$.

b. $5.0 \mathrm{ml} \mathrm{CCl}{ }_{3}-\mathrm{C} \equiv \mathrm{N} / 5.0 \mathrm{ml} \mathrm{CH}_{3} \mathrm{OH}$, surface area $5 \mathrm{~cm}^{2}$.

\section{Results}

Figure 15 shows the plutonium weight-loss rates for the reaction systems $\mathrm{CCl}_{3} \mathrm{Br} / \mathrm{CH}_{3} \mathrm{OH} / \mathrm{Pu}^{\circ}$ and

FIGURE 15. Plutonium Metal Weight Loss in the Reaction Systems: $\mathrm{CCl}_{3} \mathrm{Br} /$ $\mathrm{CH}_{3} \mathrm{OH} / \mathrm{Pu}^{\circ}$ and $\mathrm{CCl}_{3}-\mathrm{C} \equiv \mathrm{N} / \mathrm{CH}_{3} \mathrm{OH} / \mathrm{Pu}^{\circ}$.

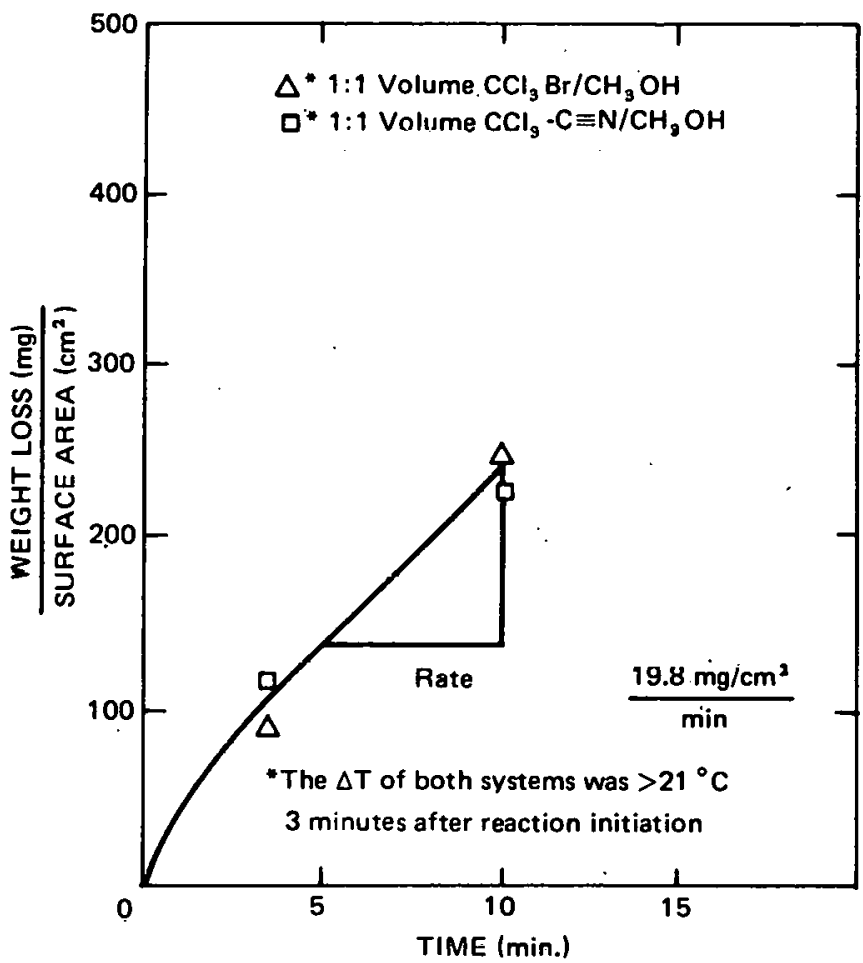


$\mathrm{CCl}_{3}-\mathrm{C} \equiv \mathrm{N} / \mathrm{CH}_{3} \mathrm{OH} / \mathrm{Pu}^{\circ}$. Reaction rates of $\sim 19.8$ $\left(\mathrm{mg} / \mathrm{cm}^{2}\right) / \mathrm{min}$ were estimated. The temperature rise exceeded $+21{ }^{\circ} \mathrm{C}$ above ambient 3 minutes after reaction initiation. Immediate reaction initiation occurred (visual observation) on immersion of the plutonium specimens in the organic solvent mixtures.

No detailed investigation of these reaction systems was accomplished. Preliminary $\mathrm{Pu}^{\circ}$ weight-loss rates $\left[\sim 20\left(\mathrm{mg} / \mathrm{cm}^{2}\right) / \mathrm{min}\right]$ appear comparable . with the $\mathrm{CCl}_{4} / \mathrm{CH}_{3} \mathrm{OH} / \mathrm{Pu}^{\circ}$ reaction systems.

One notable feature of these solvent mixtures- $\mathrm{Pu}^{\circ}$ reactions was a reduced reaction-induction period ( $<30$ seconds) compared to $\geqslant 30$ seconds for $\mathrm{CCl}_{4} / \mathrm{CH}_{3} \mathrm{OH} / \mathrm{Pu}^{\circ}$. This datum could indicate these reaction systems proceed at a lower reaction activation energy than $\mathrm{CCl}_{4} / \mathrm{CH}_{3} \mathrm{OH} / \mathrm{Pu}^{\circ}$. 